In cooperation with the:

U.S. Agency for International Development

Centre de Suivi Ecologique

\title{
CATTLE AND CULTIVATORS: \\ A STUDY OF COMPETITION \\ OVER NATURAL RESOURCES IN NORTHERN SENEGAL
}

Case Studies of Livelihood Strategies and Resource Management in the villages of Teud Bitty and Maka Ndandary

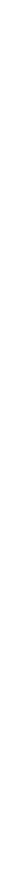

EROS Data Center U.S. Geological Survey Sioux Falls, South Dakota 57198 USA 


\title{
CATTLE AND CULTIVATORS: \\ A STUDY OF COMPETITION OVER NATURAL RESOURCES IN NORTHERN SENEGAL
}

Case Studies of Livelihood Strategies and Resource Management in the villages of Teud Bitty and Maka Ndandary

\author{
Report by \\ Karen Schoonmaker Freudenberger \\ Eric Wood \\ Research Team: \\ Karen Freudenberger \\ Amadou Moctar Dieye \\ Pape Meissa Diop \\ Moussa Drame \\ Fary Ka \\ Mamadou Ly \\ Daouda Ndiaye \\ Gray Tappan \\ Moustapha Thiam \\ Eric Wood
}

October 15, 1998 


\section{TABLE OF CONTENTS}

INTRODUCTION TO THE CASE STUDIES $\ldots \ldots \ldots \ldots \ldots \ldots \ldots \ldots \ldots 1$

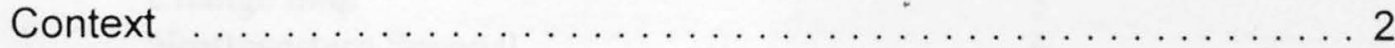

Methodology ......................... 4

About the Report and the Region Studied . . . . . . . . . . . . 10

PART I: $\quad$ CASE STUDY OF TEUD BITTY SANTHIE $\ldots \ldots \ldots \ldots \ldots \ldots 14$

Introduction to the Village of Teud Bitty . . . . . . . . . . . . . 14

Resource Management at the Territorial Level . . . . . . . . . . . . 16

Management of Resources at the Household Level . . . . . . . . 21

PART II: $\quad$ CASE STUDY OF MAKA NDANDARY $\ldots \ldots \ldots \ldots \ldots \ldots 26$

The Community of Maka . . . . . . . . . . . . . . . . 26

The Natural Resources of the Hurum . . . . . . . . . . . . . 28

Resource Management at the Household Level . . . . . . . . . . . . 29

Maka's Management of Resources at the Territorial Level . . . . . . . 34

Conflicts over Land and Resources . . . . . . . . . . . . . . 40

The Livelihood System and the Environment of Maka . . . . . . . . . 46

PART III: TEUD BITTY, MAKA, AND LAND USE PATTERNS IN THE SYLVO-PASTORAL RESERVE $\ldots \ldots \ldots \ldots \ldots \ldots \ldots \ldots \ldots$

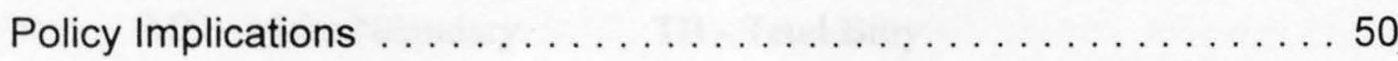

Annex 1: $\quad$ Program of RRA Field Work $\ldots \ldots \ldots \ldots \ldots \ldots \ldots \ldots \ldots$

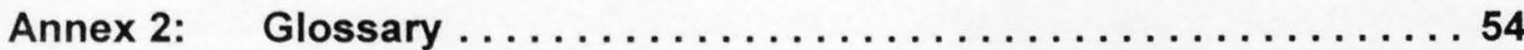




\section{List of Figures / Photographs}

Figure

Change map 5

Northwestern Senegal 6

Territorial map (TB)

17

Historical matrix (TB)

22

Wealth ranking (MN)

31

Historical profile (MN)

36

Hurum map (MN)

39

Historical matrix (MN)

48

\section{Photo}

Air photo - 1954

Trees on hurum gese

Wuro layout

(The photographs are all located on

Banded tree

New cultivation

MN - Maka Ndandary

TB - Teud Bitty 


\section{INTRODUCTION TO THE CASE STUDIES}

This study presents an analysis of the interaction of humans and their environment in the arid Sahelian zone of northern Senegal. It compares a pastoral community which lives primarily from the production of livestock and a farming community whose activities have traditionally centered on crop production. Living side by side but following different strategies for securing their livelihoods, these groups find themselves in increasing conflict over how the diminishing resources of the area should be used. The pastoral livelihood system, as practiced in the case study community of Maka Ndandary, is essentially conservationist in its approach to natural resources. It regulates the activities of community members toward the environment and employs diverse strategies to protect local resources against incursion by outsiders. The agricultural village, represented by the case study of Teud Bitty, takes a much more extractive approach to its resources. As resources have diminished over time, the villagers have become even more aggressive in their attempts to exploit what remains, whether soils or trees... both within and outside their territory.

The impact on the environment is readily apparent. A tour of Teud Bitty's territory reveals a desolate nearly treeless landscape where open patches of blowing sand alternate with fields of sparse millet stalks and scrubby fallows. No conversation about farming is complete without multiple allusions to the village's acute problems with soil fertility and references to fields which have become practically barren. Less than five kilometers away, the Maka territory presents an entirely different allure. Coming from Teud Bitty one is immediately struck by what must be considered (by the standards of northern Senegal) to be significant concentrations of trees. This is no tropical forest, but it is a visibly healthy ecosystem where even a quick inventory of the milieu reveals at least 15 species of trees, most with sizeable canopies, scattered over large area of grasslands. There is no evidence of denuded or eroding soils and, when asked about issues of soil fertility, the residents express surprise, insisting that their land is at least as fertile as it was during the time of their grandfathers.

The contrast between the impact these two communities have had on the environment is vivid. The implications take on a larger significance, however, when we note that the state has consistently favored the expansion of the agricultural system into pastoral zones due to its interpretation of the Land Law which gives preference to those who put the land to "productive" use. Until now agriculture has been considered by the authorities to be a productive use of land, whereas extensive animal raising as practiced by traditional pastoralist communities is not. As a result sustainable pastoral management systems are being progressively eroded as unsustainable agricultural systems expand their territories in order to put fertile new lands into production.

In the two case studies presented here, we look at how each community manages natural resources, the causes and consequences of conflicts over resource use, and 
the role of the state in the face of these recurrent conflicts. Ultimately, we see the impact of all these associated factors on the environment, the sustainable use of resources, and the vulnerability/viability of production systems that depend on the health of the natural resource base.

\section{Context}

This case study is one of several carried out as part the Long-term Environmental Monitoring in Senegal Project. Co-financed by USAID and the U.S. Geological Survey's EROS Data Center (EDC), and implemented by EDC and the Centre de Suivi Ecologique (CSE), this project has carried out extensive monitoring of natural resources and land use patterns in Senegal in order to better understand the complex dynamics of change in semi-arid tropics. The monitoring, as carried out by EROS staff and their Senegalese collaborators, has involved use of information collected by remote sensing (satellite and aerial photographs) as well as extensive field work including the collection of physical information about soils, vegetation, land use practices, and biodiversity at over 600 sites in all parts of the country (Tappan and Wood, 1995). This information provides a remarkable record of changes in physical and land cover parameters over the last 30 years.

It is important to policy makers, development workers, and --ultimately -- to local populations, that changes in physical parameters be observed and recorded. This type of information has certain limitations, however. By itself, it does little to explain the complex causes that have led to observed changes in the environment and neither is it of much help in explaining the impact of these changes on local populations. Some of the observed changes can be directly linked to exogenous physical factors such as changes in rainfall quantity and patterns. But human interaction with the environment at the local level also clearly has an impact. And this impact is part of a circle of change where changes in resource availability (whether soil quality, tree density, or biodiversity) in turn have an impact on people and their livelihood strategies. As resource availability and human needs change, so do people's strategies toward resource use. The environment again changes forcing people to adapt new strategies.....and so the circle continues.

For several years, the author and others have been working closely with EROS staff to consider how other types of information might be gathered that would begin to tie the physical observations with social analyses in order to better understand the issues of cause and impact outlined above. From these discussions, the EROS team decided to carry out several case studies in areas where preliminary analyses of the physical parameters suggested that further social research would be particularly illuminating in understanding the interaction of humans and their environment. The case studies were to be carried out using Rapid Rural Appraisal (RRA), a qualitative, participatory methodology that attempts to tap local people's indigenous knowledge. In this case, such information was critical to understanding their strategies for managing natural resources and the ensuing impact on the environment. 
RRA is a method that helps outsiders establish a rapport with local populations and, through a highly intensive period of field research in a given site (generally a village and its territory) to explore interactions between multiple variables. The research team lives in the village during the research phase (typically from 5-8 days), uses a variety of tools and techniques to gather information, and works with diverse groups of people as well as individuals to better understand the range of experiences and perspectives that exist within a given community. Each of these elements contributes to the team's ability to move beyond superficial explanations and to probe more deeply into the underlying strategies that individuals and communities use in their management of resources.

The approach taken by RRA studies (focusing on a single community and its surroundings but going into considerable depth) is very different from the remote sensing approach which tends to take a much broader spatial view and cannot look very deeply at any set of issues. This makes the marriage of the two methods particularly interesting since, while there should (if both methods are used accurately) be a certain limited amount of overlap in the information collected by the two (useful for cross-checking or "triangulating" in the lingo of RRA), for the most part the two methods will be collecting different kinds of information. In most simple terms, we might think of the spatial information as telling us what is happening over a fairly large area, whereas the RRA provides much greater information on the how and why by taking a closer look at a given site within the area covered by remote sensing.

The advantage of combining the techniques will become evident from this study. In the first place, analysis of the spatial information (based primarily on satellite and aerial photos) can be used to focus on areas where (1) there are dramatic differences in land use, resulting in different resource patterns across a given ecological zone or (2) there are significant changes over time in the quality or quantity of resources as monitored by remote sensing. Both of these are indicators that there may be an interesting story of human-environment interaction to be explored further. In this way, the spatial information can be used to focus the intensive, site-specific RRA on areas where the most interesting information is likely to be obtained. In this study, then, the second round of information came from RRA studies. In this case, two sites were selected in order to understand human-environment interaction in two quite different settings, one a primarily agriculture community inhabited by one ethnic group, and the second a primarily livestock rasing community inhabited by a second ethnic group. Information collected in the RRAs allowed us to analyze the impact of these two livelihood systems on the environment and thus to better understand why there were such visible differences in physical parameters (specifically tree density) that could be observed from remote sensing information taken in the area.

At this point, however, the limitations of the RRA studies become clear. While we could obtain an excellent focused view of the impact of two livelihood systems on their local environment, we could do little to evaluate the impact in a larger area.... was one system more dominant or expanding? Do the two systems occupy approximately the same surface area? To answer these questions, we went back to the remote sensing 
information. In light of the RRAs, the differences in land use patterns meant much more than they had in the preliminary analyses. But furthermore, it was rather easy to see, from current images, the differences in land coverage of the agricultural and pastoral systems. Of even greater interest, by looking at the historical record of aerial photos and satellite images from the past 30 years, we also hoped to document the evolution of land use over time.

In short, combining the two methods enabled us to understand the dynamics of humans' interaction with their environment on the micro -scale and to explore the many factors that contribute to people's strategies to conserve and/or use resources in ways that may be more or less sustainable. Using remote sensing, we were then able to look at the collective impact of vast numbers of resource management decisions (made at the individual and community level) on the broader environment and to understand what that implies in terms of environmental change over space and over time.

The purpose of these studies was multifold. We were interested in gathering information on several salient issues concerning environmental change in Senegal. It is hoped that this information will illuminate some key issues that concern policy makers, donors, projects working in areas where these issues are relevant, and will ultimately serve the local populations who are in a daily struggle to maintain their livelihoods and the resources essential to their livelihoods. Of equal importance with the information gathered in the particular sites, however, is the demonstration of the utility of combining techniques that are quantitative and "top-down" with those that are qualitative, participatory, and "bottom-up" in their approach. ${ }^{1}$ We hope that these illustrations will help others who are working on resource management issues to see how these complementary approaches might be used in their project and planning activities.

\section{Methodology}

\section{Analysis of Spatial Data}

An important source of information on the environmental context of this RRA study comes from remote sensing, specifically historical aerial photography, aerial videography, and satellite imagery. For this study, remote sensing photos and images provided the team with information on general land use and land cover patterns before going into the field. After completing the field research, the images and photos were further exploited to produce detailed land use and land cover maps of the Teud Bitty area (see Figure 1), as well as a general map of northwestern Senegal (see Figure 2). Two dates of aerial photography, 1954 (see Photo 1) and 1980, provided a unique

${ }^{1}$ For more examples of others who are working on combining these remote sensing and participatory research methods, see Cultural Survival Quarterly, Winter 1995. 
Land Use/Land Cover — Teud Biti/Maka Peul Vicinity, Northwest SENEGAL

1954

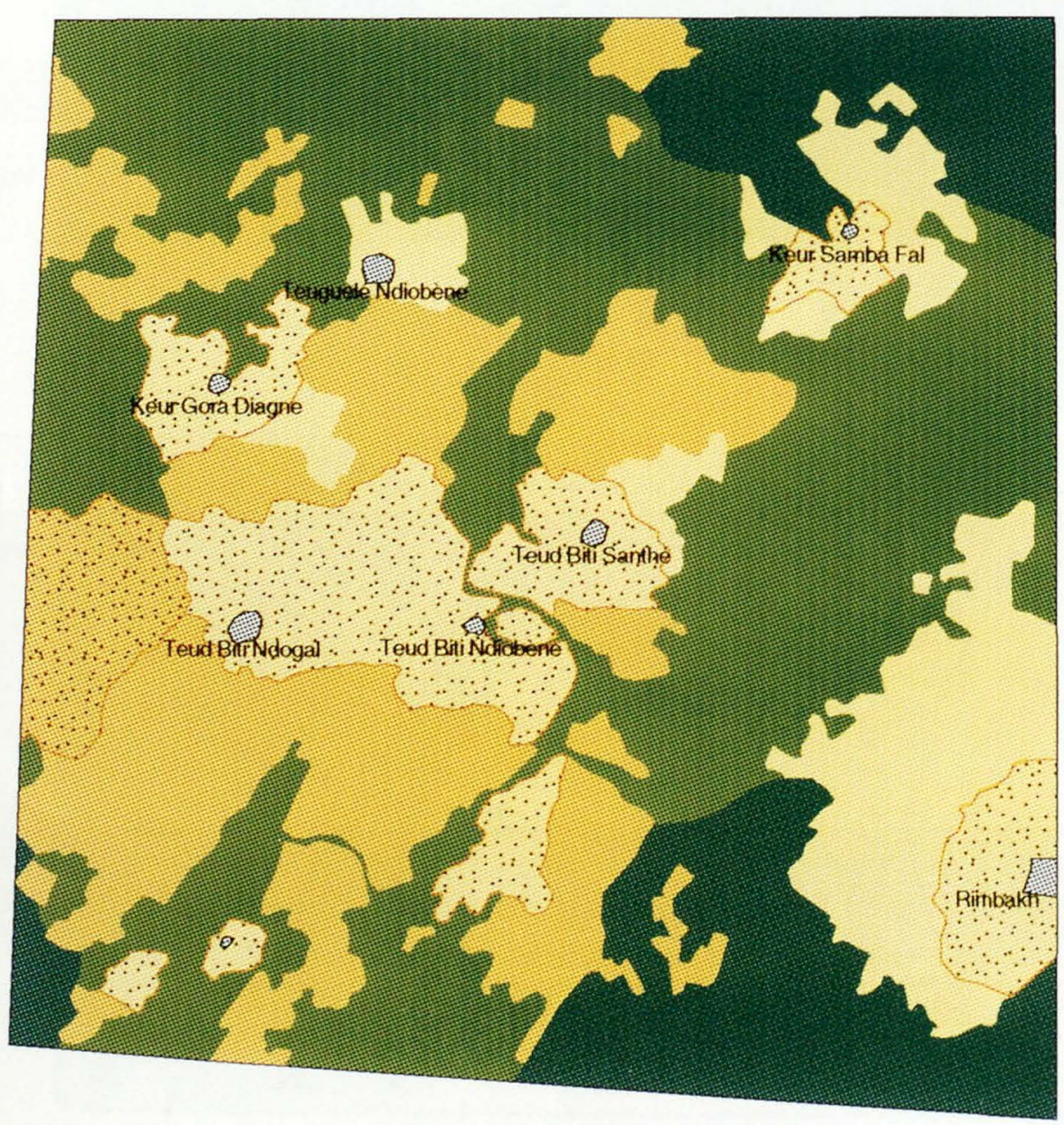

1980

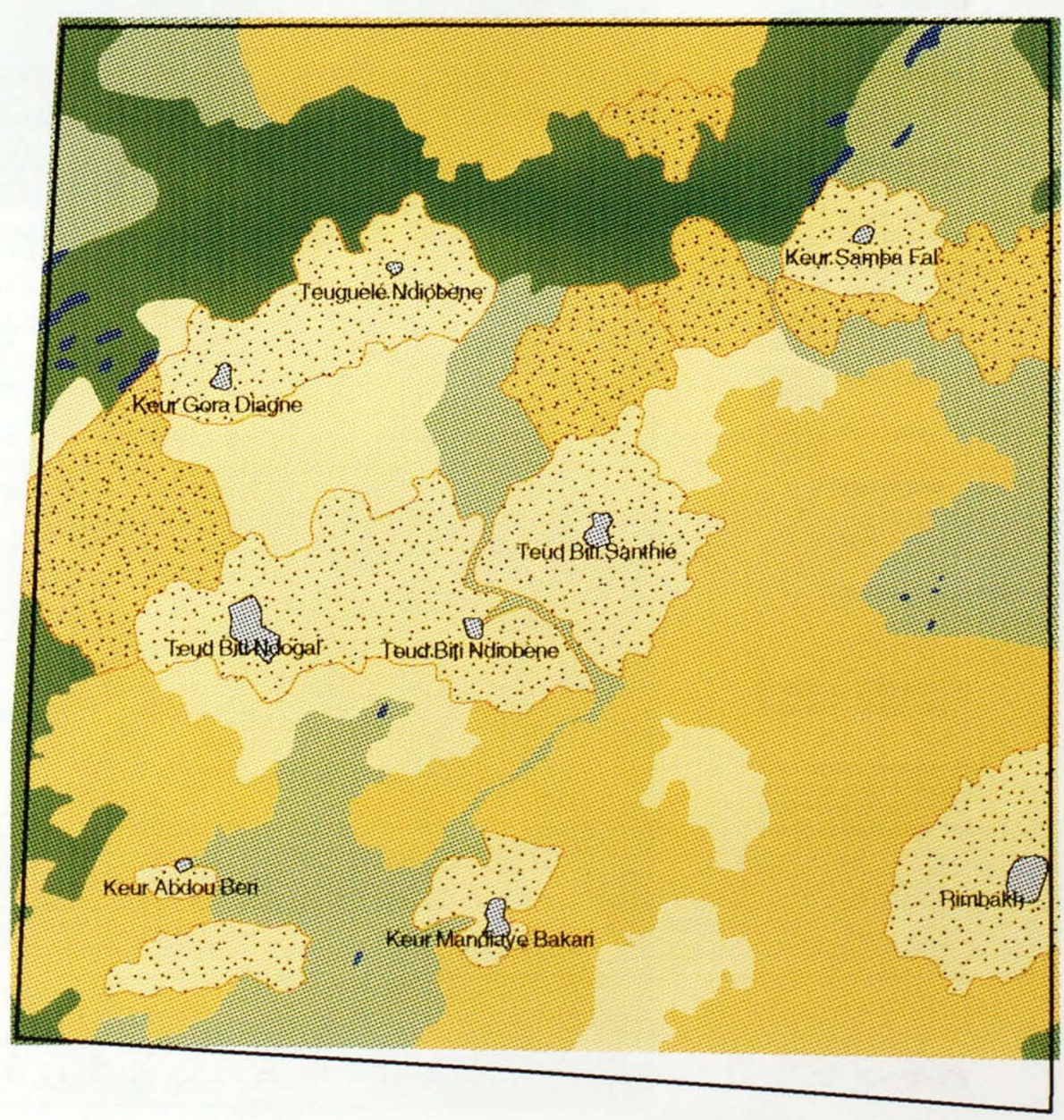


OCCUPATION / UTILISATION DU SOL AU NORD OUEST DU SENEGAL LAND USE / LAND COVER OF NORTHWESTERN SENEGAL

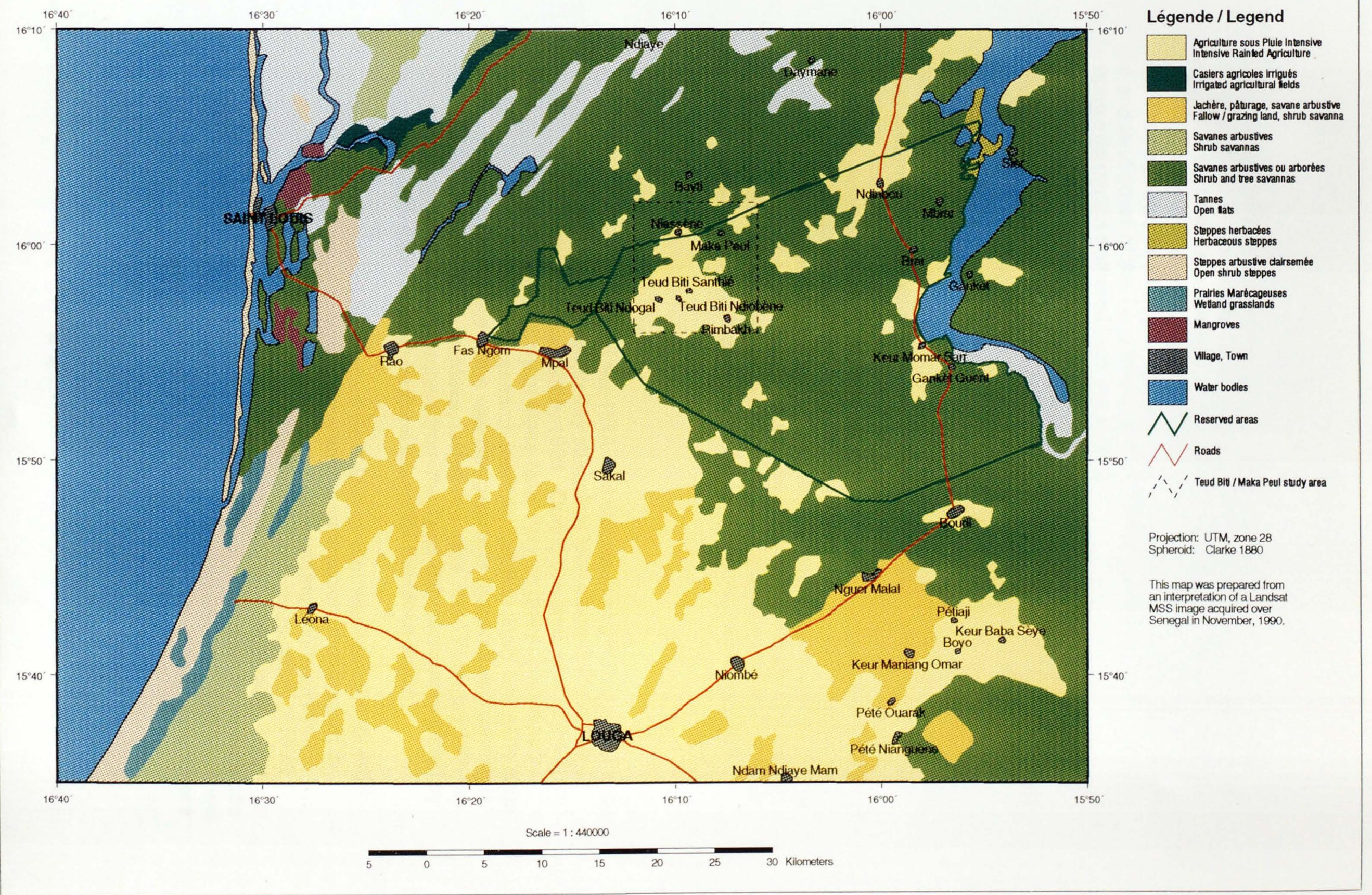



window into the recent past. A satellite image from a Landsat satellite (Multispectral Scanner data), acquired in November 1990, was used to produce a small scale map of general land use of northwestern Senegal. A second Landsat image (Thematic Mapper data) taken in 1992 was also used to measure the level of agricultural encroachment into the area. These photos and images represent an independent and objective source on land use and land cover of the Teud Bitty terroir and surrounding territories, useful for triangulating information gathered from the villagers.

The approach to exploiting the aerial photos and images was to conduct a human or manual interpretation of these data using conventional interpretation techniques. These techniques made use of photo (or image) features, namely tone, hue, texture, pattern, shape, size, shadow, and context, as well as considerable familiarity of the landscapes from earlier field surveys in the area. Point, linear, and polygonal features were delineated from the photos and images, relating mainly to infrastructure (roads, villages) and land use/land cover patterns. The aerial photos were not geometrically corrected, therefore the resulting maps contain the same uncontrolled geometric qualities as the photos. The Landsat image, however, was in a UTM projection, and the original interpretation was done at 1:500,000 scale. The final maps were not field checked for accuracy, but the team feels that they are quite accurate because the interpreter made use of ground site information collected in the mid-1980's, as well as aerial video images acquired in 1994 from a very low altitude (800 feet above ground). Topographic maps at 1:50,000 scale, published in 1990, also served as a reference for village names for general information.

\section{Rapid Rural Appraisal}

This comparative case study comprised two RRA field studies in neighboring territories in northern Senegal. The first was a seven day study that took place in the village of Teud Bitty from January 19th to January 26th, 1996. During this time, part of the team spent one day in the neighboring territory of Maka Ndandary, to gather preliminary information from this second site. The research team for this first study was quite large (seven people) because the purpose of the exercise was both research and training in RRA techniques. The second study, in Maka, lasted five days, from February 14th to February 19th, 1996. Two of the researchers from the Teud Bitty team were joined by two new researchers with experience in pastoral issues for the Maka study.

Site Selection. The area west of the town of Keur Momar Sarr was selected for this study because preliminary rapid analysis of the spatial information from the EROS project in Senegal suggested that this was an area that is undergoing significant environmental change. In addition, the Centre de Suivie Ecologique (CSE), EROS' partner in Senegal, is working closely with an NGO (ASREADE: Association

Sénégalaise pour la recherche et l'appui au développement) in the area to analyze and use spatial data for development planning purposes. Since several CSE staff members were to be trained in RRA during this exercise, it made sense to choose an area where 
the information could be put to immediate use by CSE partners working on development activities in the region. A preliminary visit which included a member of the research team was carried out to visit a number of villages in the region and to select the site for the RRA. Among the criteria used to select the study site were (1) the apparent interest of environmental issues in the site (initial discussions in Teud Bitty revealed the residents' preoccupation with these questions, (2) logistical considerations (such as the ability of the village to accommodate a team of ten people without unduly disrupting local activities, and (3) the village's expressed interest in participating in the RRA.

The choice of Maka Ndandary was really a result of serendipity. During the research in Teud Bitty, which included visiting the territory and neighboring areas in order to observe and discuss resource management issues with our village guides, we noted an area that was considerably more wooded than anything we had seen in Teud Bitty. Further questioning revealed that this area was controlled by Pulaar pastoralists, rather than by Wolof farmers as in Teud Bitty and several neighboring villages. This immediately raised interesting questions for the team. The Pulaar herder in Teud Bitty was able to direct us to leaders in Maka and, by tracking down these people, we made our initial contacts there. The one day spent in Maka (doing some very sketchy maps and a historical transect) convinced us that there was much to be learned by doing a more systematic, comparative study of the two systems and the decision was made to return to the area to complete the study a couple of weeks later.

The teams. In the selection of both teams, careful attention was made to balance the teams and to ensure representation from various disciplines and other perspectives. The research team in Teud Bitty was composed of the following people:

Karen Schoonmaker Freudenberger, social scientist (team leader)

Amadou Moctar Dieye, cartographer/geographer

Pape Meissa Diop, agro-forester

Moussa Drame, forester

Daouda Ndiaye, development worker in the region

Moustapha Thiam, Veterinarian/pastoralism specialist

Eric Wood, remote sensing specialist

Sega Mane, translator (Wolof/French)

The team was accompanied by the team leader's 3 year old daughter and her babysitter, the presence of whom did much to facilitate our integration into village life.

In Maka Ndandary a smaller team included two of the Teud Bitty researchers as well as two new team members from the NGO Associates in Research and Education for Development (ARED). ARED specializes in working with Pulaar populations on literacy, publication of books in local languages, and associated development activities. Karen Freudenberger and Moustapha Thiam, who had been members of the Teud Bitty 
research team, were joined in Maka by Fary Ka (linguist with extensive personal experience in pastoral activities) and Mamadou Ly, who has worked with pastoralists to adapt and use Participatory Rural Appraisal techniques to analyze their local situation and plan their own activities.

The research program. The daily schedule of activities for each case study is included in Annex 1 at the end of this report. In both cases, the teams made considerable efforts to employ a range of RRA tools that would permit resource management issues to be studied from different angles. The tools used included participatory mapping, transect walks and rides (with guides in a pick-up truck), Venn Diagrams of social relations, historical and ranking matrices, bean quantification, historical profiles, wealth ranking, and semi-structured interviews. Some of the activities were carried out with large groups of people, while others were done with smaller groups or individuals. The team took special pains to ensure that diverse perspectives of community members were included in the analysis by soliciting the participation of people of different age groups, wealth and influence status, and gender. We were generally successful in these efforts, though we found it difficult in Teud Bitty to get adequate representation of women's views. Even when women were present at activities, they did not participate actively in most cases. We had more success when we oriented activities specifically toward small groups of women, but even then we sensed considerable reticence. We think that the situation in Teud Bitty was related to the strong outmigration as a result of economic necessity. The more outgoing and dynamic members of the community are the most likely to outmigrate in search of seasonal employment and were for the most part not present during the period of out study. We did not encounter this problem in Maka, where the women were often more outspoken than the men, both in mixed groups and when interviewed by themselves.

In both cases, the field work ended with a presentation to the village of what we had learned from them. This gave the people in attendance the opportunity to correct any problems they identified with the hypotheses presented by the team, organized the information into a form in which they could more easily use it for their own purposes, and provoked discussions on how the practical implications of the research for their own planning/development purposes. In both Teud Bitty and Maka, the villagers proposed ways in which they might use the information -- and the momentum to look at these issues built up during our stay -- to take action to resolve problems that concerned them.

Limitations of the study. We were, for the most part, very pleased with the information gathered and the research process that was carried out in these two studies. We felt that the team learned a great deal during the exercise but that the villages where we stayed also profited from their participation by clarifying issues of concern, analyzing the ramifications of certain resource issues, and focusing on lingering problems in order to work out solutions based on their own knowledge and local capacities. 
The research process is never perfect, however, and we prefer that readers know our limitations as they consider the information we present here. First of all, we would have liked to have had more time for both studies. We felt particularly constrained in Maka Ndandary where we were dealing with issues where the team had less collective experience to draw on. We feel confident, due to consistent efforts to triangulate (cross-check and verify) information, that the results we present here are accurate, but we feel that there are still certain gaps that could have been filled had we had longer in the field and certain subjects that we would have liked to probe further.

Had we planned to do a comparative study from the outset, we probably would have attempted to more systematically gather directly comparable information from the two sites. We feel that the information we have is strong enough to make the arguments laid out in our conclusions, but there may be specific points where directly comparable information is not available due to this shortcoming. RRA thrives on serendipity and flexibility and we took advantage of these characteristics of the methodology to the maximum in carrying out this study. But that doesn't mean that we might not have done it differently had we known more about what we were getting into when we started out!

Finally, the team was acutely sensitive to issues of bias as we carried out the study and studiously attempted to counteract biases wherever we were able to identify them. In most cases we are confident that we were highly successful in our efforts to neutralize these problems as we identified them. In two cases, we felt that we were only partially successful. The first was the gender bias noted above (see Research Program) in Teud Bitty. The second was the bias of expectations, which was also particularly strong in Teud Bitty. It is understandable that in a village whose economy is as precarious as Teud Bitty's the population should always be on the lookout for outside assistance with their problems. The Teud Bitty population did not miss an opportunity to present their concerns. In both Teud Bitty and Maka, the shortage of potable water was an issue that surfaced in nearly every activity conducted by the team. We often had the impression that the Teud Bitty village chief was taking great pains to choreograph our visit so that these issues were highlighted. (This was not difficult to do since the provision of potable water was one of the major logistical problems for the team itself in the two sites.) While sympathetic to the plight of the village in this regard, we also had to be honest that this was not a problem that our study could, at least in the short term, directly resolve. At times to divert the discussion away from these topics and to the issues that more generally interested the study, we were obliged to distract the chief (by taking him off on an activity or private interview by one member of the team) so that the rest of the population could work on other issues.

\section{About The Report and the Region Studied}

Following this introductory chapter, Part I of this report presents the case study of Teud Bitty. Part II them presents the case of Maka Ndandary. In each example, the study begins with an overview of the community, focusing on its history, current social 
situation, and principal livelihood activities. The second part of each of the studies looks at the management of resources at the macro (territorial) level. It describes the state of the resources and how the community is organized to manage the territory and the resources found in it. This is followed by a section that treats the micro (household) management of resources, looking at issues that arise as different families go about assuring their livelihoods. In this section we attempt to disaggregate the information by relative wealth category so that differences in the way families manage resources depending on their relative affluence are highlighted. Each case study concludes with an analysis of how management strategies at the macro and micro level affect the health of the natural resource base, ending with concluding comments summarizing the situation observed in each site. The report concludes with a final chapter comparing the overall situation in the two sites and returning to the spatial information available from remote sensing techniques to analyze the implications of these findings for policy makers, local development organizations, and the communities themselves.

Before we get to the individual case studies, however, the following section introduces the reader to the general geographic situation of the study area since the information applies to both villages where research was carried out.

The village of Teud Bitty Santhie (there are several Teud Bittys in the area) and the community of Maka Ndandary are both located in the Louga region of northern Senegal (see Figure 2). Maka's territory actually lies at the frontier of the Louga region, where it abuts the region of Saint Louis. Both lie in the Communaute rurale and the arrondissement of Keur Momar Sarr. They are accessible only by a sandy track that links Mpal (on the main road north from Louga to Saint Louis) with Keur Momar Sarr, the arrondissement capital that is on the banks of the Lac de Guier, Senegal's only significant fresh water lake. The territories of both sites are approximately equidistant between the road and the lake: a distance of $20-25 \mathrm{kms}$ in each direction. There is a major market that takes place in Mpal twice a week as well as smaller local markets (such as that of Niassene) which serve both communities.

Local administrative authorities (the sous-prefet, extension agents, and Communauté Rurale officials) are located in Keur Momar Sarr which is accessible by public bush taxi. The populations expressed a sentiment of neglect at the hands of the authorities, due principally to the fact that they are located at the very periphery of all four jurisdictions (communauté rurale, arrondissement, département, and région). For their part, the authorities decry the lack of transport to such outlying areas and admit that they are severely constrained in their ability to deal with problems that arise so far from their base.

The area around the edge of the Lac de Guier is waalo land that floods seasonally. These lands tend to be rich in sediment and can be irrigated by canal systems that run off the lake. They are highly coveted for plantations of vegetables and fruit trees. Moving away from the immediate influence of the lake, one passes into the dry jeer $i$ 
lands. The water table quickly gets deeper and the topography is characterized by stabilized sand dunes. The upper parts of the dunes have light sandy soils, while the interdunal valleys have slightly heavier soils that are mixed with some clay. Most of the jeeri land to the west of Keur Momar Sarr, roughly $50 \mathrm{kms}$ to the Louga-Saint Louis road is classified as a sylvo-pastoral reserve. Both Teud Bitty and Maka are situated approximately in the middle of this reserve, known as the Sylvo-Pastoral Reserve of Pal-Mérinaguène.

The Pal-Mérinaguène reserve is a relic of the French system of creating protected areas where the land was considered too marginal for peanut cultivation due to the nature of the soils and the limited rainfall. This sylvo-pastoral reserve continues to exist on paper. This means that, in principle, peanut cultivation is not permitted within the reserve and any land allocation passes through the Eaux et Forets (which is responsible for managing such reserves) rather than the Communauté Rurale which allocates lands not covered by Reserve regulations. In fact, however, as will be described in this study, the official Reserve status no longer has any noticeable effect on the way resources are managed. It appears from our discussions with the Communauté Rurale president that the Council treats land in the Reserve as it treats other land under its jurisdiction. For his part, the Eaux et Forets agent who is technically responsible for managing the reserve was only vaguely aware of its existence saying that to be sure he would have to check the records to see whether it had ever been declasssified.

The entire area is characterized by low and highly variable rainfall. Over the 12 year period from 1980-1992, average rainfall in Keur Momar Sarr was 258 mm per year, with rain falling on average on 15 days during the year. Rainfall varied from a low of $63 \mathrm{~mm}$ to a high of $426 \mathrm{~mm}$. In order to better understand the implications of changing rainfall patterns in the area, we can compare these recent figures with historic data from Louga for the period 1931-1960. Over this period, the average rainfall was $473 \mathrm{~mm}$ and the lowest rainfall recorded was $239 \mathrm{~mm}$. This declining rainfall has had a dramatic effect on the disappearance of many tree species, specifically the sudano-sahelian species such as ficus steophylla, commiphora africana, sterculica setigera, etc. which require higher rainfall, as well as on the viability of agricultural production in the region. Some crops, such as manioc, have been largely abandoned due to low rainfall, whereas others are still cultivated but produce significantly lower yields due to factors which include rainfall shortages. Crop cultivation has always been precarious in the zone, due to the extreme variability of rainfall, but the overall reduction in rainfall has dramatically increased farmer vulnerability, as we shall see particularly in the Teud Bitty case study.

The area suffers generally from water problems due to the salinization of superficial aquifers that can be tapped by artisanal techniques accessible to the local population. The shallow wells in both Teud Bitty and Maka are too saline for use as human drinking water and are used only for animals. As a result both drinking and bathing water must be sought from neighboring villages where there are tubewells which pump water from deeper aquifers. The populations pay for this water (in Niassene the cost is $125 \mathrm{cfa}$ for 
a barrel) and transport it in barrels or large inner tubes using horse or donkey carts.

For the recent historical past (the last 100 years), the zone has been inhabited principally by Wolof farmers and Pulaar pastoralists. These descriptions reflect the identity that each group wishes to project more than the reality of today's production system. One peculiar twist in the current situation (as will be discussed in the case studies) is that in many cases the Pulaar now produce more crops than their Wolof neighbors in spite of their continued insistence that crop production is, for them, a very minor activity. There are also a small number of Maures who have settled in the area.

With this brief introduction to the area, we now turn to focus on the two communities studied in this research. 


\section{PART I: CASE STUDY OF TEUD BITTY SANTHIE}

\section{Introduction to the Village of Teud Bitty}

The Population of Teud Bitty. Teud Bitty was founded in about 1908 by Wolof settlers from the Senegal River region who were fleeing repression by their Mauritanian neighbors. The village was founded by Yatma Binta Diop who was accompanied by nine other heads of family. As the founding family, the Diop clan has remained instrumental in the life of the village and the chief is always selected (by the entire village) from among the most senior Diops. Abdou Khouna Diop, the current village chief, is also the community's representative on the Communauté Rurale council.

When the village was originally settled, the founding Diop family allocated land to the others who had accompanied them. When families have joined the village during the intervening years, the same practice has been followed, and the chief allocates land to the newcomers from the traditional Diop holdings (which are considerably larger than those held by any other family).

In addition to the nine family groups that now comprise the population of Teud Bitty, there is a Pulaar herder who lives at the edge of the village and takes care of the population's livestock. Originally from Maka, he has been a resident of the Teud Bitty for three years. He is the fifth herder to have lived in Teud Bitty, with the others staying between one and ten years.

The official population of Teud Bitty is approximately 600 people. In fact, however, only a small percentage of this population actually lives in the village. About $1 / 3$ of the population is on "permanent" emigration, defined here to mean that they do not live any part of the year in the village, and return only to participate in special family or community occasions. Roughly half the population leaves the village during the long dry season in search of paid employment. This number includes all social categories, men and women, married and unmarried. Only about $1 / 6$ of the population (or 100 people) stay in the village year-round.

Both seasonal and permanent emmigration are driven primarily by economic necessity. Seasonal workers head mostly for Saint Louis and Richard Toll. Women find work as maids or work in the industrial rice, tomato, and sugar plantations along the edge of the Senegal River. Men also do seasonal agricultural work and anything else they can find, including taxi driving and petty commerce. While some people gain reasonable salaries from these activities, most earn only paltry sums either in cash or kind. However, their absence means that there are less mouths to feed in the village and whatever they can send back (often rice gleaned from the Richard Toll plantations) is a welcome contribution to village food stocks. 
The social consequences of such massive outmigration are substantial. While seasonal migration is a common phenomenon in agricultural villages throughout Senegal (due in part to the very long dry season when there are few remunerative activities in most villages), migrants are usually unmarried people and some male heads of family. In Teud Bitty, just about all the "active" population (those that are not enfeebled by age or sickness) leave the community. This is highly disruptive of family life and women, especially, complained bitterly about the hardship of leaving their children behind in the care of elderly people. It also affects the ability of the village to engage in collective decision making and to carry out community based actions to solve local problems since the most dynamic people are absent for large parts of the year and those who remain behind often do not have the authority to commit their family to decisions that are made in the absence of the senior family members.

In addition, outmigration has numerous economic implications. Certain village economic activities, such as animal raising, which extend beyond the limits of the rainy season become unviable because there are not enough people to care for the animals when the bulk of the family labor departs. If, as discussed below, animal production were to became a larger part of the local livelihood (reproducing certain pastoral strategies which have proved themselves effective in the area), the overall livelihood system would be stronger and the need for outmigration would diminish. This option is at the moment constrained, however. The initial start-up costs to get to the point where the animals are productive enough to support a larger population are prohibitive both in terms of the capital to buy the animals and the need for people to stay in the village to look after them.

The outmigration of able-bodied men, who generally take the family horse or donkey cart with them when they leave, has also resulted in major problems for the transport of water. Since there is no potable water in the village, each family is obliged to find some means to transport water from a neighboring village. This creates a tremendous demand for transport, especially when all but a few of the carts have left during the outmigration. Those few families where the cart (and presumably the able bodied labor to operate it) have not left the village need to find ways to earn money to buy the food and other necessities they need to survive. The result is that these few families with carts charge very high rates to transport water from Niassene, just five kilometers away. A basin of water that costs 125 (\$.25) francs at the tap in Niassene, will be sold by village men for 600 francs $(\$ 1.20)$ in Teud Bitty. It is the women of Teud Bitty who pay these fees, often to their own relatives. This is one of the most onerous economic burdens for women in the village.

Infrastructure and Village Layout. The village is configured in the traditional way with large family concessions grouping people with, for the most part, the same family name. There have been efforts to rearrange the village in the "squared off" configuration favored by the authorities, but the founding Diop family (which has the most to lose if land in the fields directly adjacent the village are reallocated to permit the expansion of compounds) has opposed this move. It is generally favored by the poorer 
families who would have the most to gain from such a reorganization. The village has a small shop (run by the women's association) that was financed by an NGO project and opened last year, a diesel operated millet grinding machine, and an Arabic school.

\section{Resource Management at the Territorial Level}

\section{Fields}

The territory of Teud Bitty is organized in the form of a classic Wolof village (see Territorial Map - Figure 3). The inhabited part of the village is at the center of the territory. Around this inhabited nucleus are two concentric rings of fields. The smaller ring, immediately surrounding the village is comprised of "tooker" (a local derivative of toll keur. house fields). Beyond this is a much larger circle of outer fields. In the past, there was an intermediate ring between the tooker and the outer fields. This was called the lacke.

Traditionally, the tooker fields were the most intensively cultivated. In the past, the tooker was fenced by its owner and household wastes and any animal manures from the compound enclosures (where animals spend the night) was deposited regularly on these fields. The household granaries are generally found in the tooker. These fields are managed by the oldest male in the family. He distributes portions of the tooker to various members of the family, but they are most often farmed by the elderly because of their ease of access. Other members of the family get fields in the lacke and outer ring. Since the tooker is well fertilized, the soils are generally too rich for peanut cultivation. It is mostly cultivated in millet with some bissaap (hibiscus). Currently, the tooker are generally not fenced.

The lacke fields were also usually fenced in the past with live fencing in order to separate them from the outer fields. This was important because manioc was often planted in the lacke. Since manioc stays in the field longer than the other crops (principally peanuts and millet) cultivated by in the village, it was necessary to fence these fields to keep animals out during the dry season when they were freed to use the outer fields as pasture. In general, because these fields were closer to the village and easier to survey, higher value crops were planted in the lacke. With the diminution of rainfall over the past 20 years, the cultivation of manioc has virtually disappeared. As a result, there is no longer any reason to fence the lacke, nearly all the live fences have fallen into disrepair, and the lacke and the outer fields serve essentially the same purpose. 
The outer fields are a checkerboard of millet, niebe, melon, and peanut fields, interspersed with fallows. There is no fencing in the outer fields. Traditionally, these fields were subject to a rotation of crops (millet/peanuts) every 1-2 years. There was no provision for fallowing of these lands and, in the past when most of the village participated in farming activities, much of the territory was put into cultivation each year. Now, a significant portion of the territory is in fallow at any given point in time, due in part to the very low soil fertility on some fields which have become virtually barren and in part due to labor shortages. These fallows are scattered across the territory since each family decides individually which land they will cultivate and which to leave uncultivated in a given year.

The lacke and outer fields have traditionally been divided into large family fields and individual fields. The senior male of the extended family is in charge of allocating the fields on family land. In the past, there would often be a family field of millet in the outer ring, as well as a family manioc field in the lacke. Individuals might also be allocated fields in each area by the senior member of their family. They would work each morning on the family field, and then spend the afternoon on their individual parcels. While the notion of family and individual fields continues to be a management practice, for the most part there is no longer any significant difference between the lacke and outer fields. They have become one zone, for all practical purposes with millet and peanuts cultivated throughout.

The fields of the village are gradually covering a larger area, despite the fact that the amount of land actually under cultivation at any given point in time is progressively diminishing. As the traditional fields of the village are abandoned due to abysmal soil fertility, the residents are trying to expand into new and more fertile areas. In many cases this has involved expanding fields into areas that have traditionally been used as animal passageways by herds from throughout the area. These passages provide access to pastures and watering holes. Whereas, in the past, there was a passageway that completely encircled the territory of Teud Bitty, now there is a passage on one side of the village only, and it is being narrowed each year as new fields are put into production. Currently, some of the passageways that the animals must pass through to reach the outer grazing areas are less than 10 meters wide.

\section{Trees}

The inhabited part of the village has a variety of trees, including shade trees (such as Neem and prosopis), fruit trees (such as oranges) and multipurpose trees (such as baobabs). Trees within the village are generally protected from cutting by both the local inhabitants and outsiders. Trees have fared less well outside the inhabited spaces. There are some trees in the tooker because these spaces are respected by villagers and outsiders alike as "private" spaces where any intervention must be cleared by the owner. The limits of these fields are generally more evident due to live fences in many areas and their proximity to the village and daily activities permit a more rigorous surveillance of what is happening there. In the lacke and outer fields there is hardly a 
tree to be seen. An occasional lone specimen can be observed but, for the most part the fields are devoid of any significant woody vegetation.

The absence of trees is due to several interrelated factors. Many of the less drought resistant sudano-sahelian species died out progressively between 1945 and 1965, as rainfall slowly declined. This die-back was accelerated during the droughts of 1972/3 and 1983/4 when large numbers of trees were decimated. During the seventies and eighties there was significant charcoal production in the area. The dead trees attracted charcoal makers from outside the zone, and local people also participated actively. As the diminution of rainfall compromised agricultural activities, local populations began desperately to look for alternative ways to earn their living. Once all the dead trees had been cut and put into production, the outside charcoal makers moved on. But agricultural production remained a dubious undertaking and local residents who had been accustomed to earning money from charcoal production turned instead to cutting live trees to supply their artisanal kilns. This practice was facilitated by the absence of enforced rules against cutting trees in any fields that were not fenced. In practice, anyone may cut trees on lacke and outer fields without asking permission or risking censure. The exception to this generalization are two farmers who from their "love of nature" have insisted that trees on their lands not be cut. In at least one case, the farmer has purposely maintained the live hedges around his lacke to indicate ownership and the requirement to ask permission before cutting a tree. As a result, his lacke is noticeably more wooded than any other field in the territory.

\section{Management of grazing areas}

The history of the grazing space, or barlou, in Teud Bitty offers a sad testimony to the difficulty the population has encountered in organizing its community resource management strategies. From the time the village was founded until approximately 1975 , Teud Bitty maintained a common space known as the barlou. The barlou was an area just outside the tooker on the northwest side of the village in an area where the water table was relatively shallow and access to seasonal ponds (mares) was easy. This area served as a local pasture for the animals, particularly during the rainy season when the animals did not have access to the fields for grazing. During the dry season, animals would congregate in the barlou before being driven to the outer fields or more distant pasture areas. As such, the barlou played an essential role in the collective management of the village's animal population. The barlou was maintained by a consensus decision of the community and was enforced by the chief.

The land in the barlou, having never been cultivated and having been fertilized by contributions of generations of animals, was extremely rich relative to the other land of the territory. It is perhaps not surprising that the families on whose land the barlou had originally been created (members of the founding Diop family) began to covet these lands. Their desires were held in check for many years, but when a chief came to power who was more lax in his surveillance of the issue, these families began, bit by bit, 
to encroach on the barlou. The barlou is entirely cultivated now. The current chief claims to recognize the importance of the barlou for animal management, particularly as people are investing more in small animals. He says that the women of the village, in particular, have been pressuring him to reinstitute the barlou. But he finds himself in a delicate position vis a vis the rest of the Diop family which continues to insist on their rights to cultivate the land. The issue is currently unresolved.

The absence of the barlou and the gradual reduction of animal thoroughfares poses a serious constraint, (along with the shortage of water and absence of people to care for the animals during the dry season) to successful animal raising activities. Because there is no near pasture that can be used during the rainy season, animals must be herded for up to two hours to areas where they can graze safely out of range of village crops. The animals are thus unable to build up the reserves they need for the long dry season when both fodder and water are in short supply. In addition, there is always the risk of conflict if the animals enter a field during their daily sorties since they must pass through the narrow passageways, often unfenced, that are bordered by croplands on both sides.

Other villages resolve this problem by setting aside zones where all the fields will be put into fallow for several years. These lands, all on one side of the village, serve as pasture areas during the rainy season. Often, the common fallow is transferred from one side of the village to the other after several years and there are provisions to compensate families who may not have adequate crop lands when their properties are decreed to be in the fallow pasture area. This is the case, for example, in Maka Wolof, a small village of four families just to the north of Teud Bitty. Livestock plays a considerably more important role in the livelihood pattern of Maka Wolof than it does in Teud Bitty. In order to protect their livestock interest, the families of Maka Wolof agree on an eight year rotation of fallow zones with cultivated zones. This system facilitates the regeneration of soils which are fertilized by animal manure during the rainy season and permits the regeneration of ligneous plants which stabilize soils and also contribute to fertility during the eight years of fallow. Organized fallows also make much more efficient use of the space in the territory than the patchwork of cultivated and fallow fields one observes in Teud Bitty since small isolated fallows that are enclosed by other fields serve no useful purpose for livestock. 


\section{Management of Resources at the Household Level}

\section{Agricultural Production and Food Security}

Life is difficult in Teud Bitty. The livelihood system is perhaps best described by the residents themselves: "we make do as best we can." But, each year it is a struggle just to keep food in the bowl throughout twelve months of the year. While historically the residents of Teud Bitty describe themselves as farmers, in fact their agricultural activities feed the population for only a very small portion of the year. This is not necessarily a new phenomenon in this region which has always been relatively marginal for agricultural production. Even as far back as fifty years ago, families consumed their cereal crops for only three (in years of bad harvest) to six (in years of good harvest) months a year. An average harvest could be consumed over a four month period (see Historical Matrix - Figure 4).

With reductions in rainfall quantities and increases in the variability, the productivity of agriculture has declined yet further. The average yields for millet in the Keur Momar Sarr arrondissement are less than $250 \mathrm{~kg} / \mathrm{ha}$ and we can estimate that Teud Bitty's yields are probably even lower than this since they have no systematic mechanism for maintaining soil fertility. Residents estimate that currently in a good year the cereals produced by a "typical" family will last for about three months. In an average year, the harvest can be consumed for a month and a half, and in a bad year, the grains will last for less than a month. In reviewing the last ten years, residents described two (the most recent) as being "good" years, three as "average", and five as "poor". In short, cereal production currently provides little more than a token contribution to food security in most years: in half the last ten years grains lasted for last than a month in feeding the typical family in the village.

In the past, part of the deficit was compensated by the sale of peanuts. At the current time, however, the population faces major difficulty in obtaining sufficient peanut seed and yields are low on the fields that are put into production. Peanut yields in the arrondissement are on average less than $300 \mathrm{~kg} / \mathrm{hectare}$ and we would expect that Teud Bitty's harvests are even less than this. According to our interviews, a family who is able to obtain peanuts might use about $100 \mathrm{~kg}$ of seed that, under favorable conditions would yield about a ton of peanuts. At current prices, these peanuts could be sold for approximately 120,000 francs $(\$ 240)$. A good part of this money is used to pay off debt from the year before and most of the rest is allocated for payment of taxes, medical expenses and clothes. Only a small part of the groundnut revenues are used to buy grains for the current season; families estimated that they might purchase up to $100 \mathrm{~kg}$ of millet with the proceeds of their groundnuts. 
Teud Bitty

\begin{tabular}{|c|c|c|c|c|}
\hline & 1945 & 1970 & 1985 & Present \\
\hline $\begin{array}{l}\text { Population staying in TB } \\
\text { year-round }\end{array}$ & $\begin{array}{l}\cdots \bullet \\
\cdots\end{array}$ & $\because \because \therefore 12$ & $\because \bullet \bullet 10$ & $\because \because \bullet 9$ \\
\hline $\begin{array}{l}\text { TB Natives who are } \\
\text { permanently non-resident }\end{array}$ & $\bullet$ & $\because$ & $\because \bullet \quad 7$ & $\because \cdots \bullet 9$ \\
\hline $\begin{array}{l}\text { TB population that } \\
\text { outmigrates seasonally }\end{array}$ & $\because$ & $\because \because \bullet 10$ & $\because \because \because \bullet$ & $\because \because: \because \bullet: 16$ \\
\hline Size of Territory & $\because \because \bullet 11$ & $\because \because \because \bullet_{11}$ & $\because \because \because \bullet 11$ & $\because \because \because \because$ \\
\hline $\begin{array}{l}\text { Size of Territory under } \\
\text { Cultivation }\end{array}$ & $\because \because \because$ & $\bullet \bullet 6$ & $\bullet \bullet \bullet$ & $\bullet \bullet \bullet$ \\
\hline Density of Trees & $\because \because \div 18$ & $\because \because \because \bullet$ & $\because \bullet$ & $\bullet \bullet$ \\
\hline Biodiversity of Tree species & $\because \because \because: 8:$ & $\because \because: \bullet 14$ & $\because \bullet$ & $\bullet$ \\
\hline Quality of Soils & $\because: \because: \bullet 17$ & $\because \bullet \bullet 10$ & $\bullet \bullet \bullet$ & $\because \bullet$ \\
\hline Number of Cattle & $\because \because \because: 13$ & $\because \because \because \bullet 15$ & $\because \bullet \bullet \bullet 10$ & $\because \because: \bullet: 12$ \\
\hline Number of Sheep/Goats & $\because \because:: \div 16$ & $\because \because 8$ & $\because \because: 10$ & $\because \because: 0: 20$ \\
\hline Availability of Potable Water & $\because \because:: 15$ & $\because \because \because:$ : & $\because:$ & $\because \bullet$ \\
\hline $\begin{array}{l}\text { Availability of non-potable } \\
\text { water in wells (animals) }\end{array}$ & $\because: \because: 12$ & $\because \because: 0$ & $\because \bullet$ & $\because:$ \\
\hline $\begin{array}{l}\text { Availability of water in } \\
\text { seasonal ponds }\end{array}$ & $\because 3$ & 2 & $\bullet$ & 0 \\
\hline $\begin{array}{l}\text { How many months a harvest } \\
\text { lasts in a "good" year }\end{array}$ & $\because \bullet 6$ & $\because:$ & $\because$ & $\bullet \bullet$ \\
\hline $\begin{array}{l}\text { How many months a harvest } \\
\text { lasts in an "average" year }\end{array}$ & $\because$ & 2 & •・ & 1.5 \\
\hline $\begin{array}{l}\text { How many months a harvest } \\
\text { lasts in a "poor" year }\end{array}$ & $\cdots$ & - & - & $<1$ \\
\hline
\end{tabular}

This historical matrix was carried out by a group of people that included three older men. four younger men. and three women. The group placed beans in the different matrix squares to represent relative changes over time. All numbers in the matrix are relative and should be used only as indicators of broad trends. The exception is in the last category: the number of months people eat from their grain harvest. In this case the number of beans reflects the actual number of months the harvest lasted in good. average, and poor years during each time period. Among the trends worthy of note are the significant deterioration in the categories of biodiversity, tree density, and soil quality and the drastic reduction in potable water. Harvests have declined from providing an average of 4 months of food in 1945 to $11 / 2$ months of food at the present time. 
In most years, then, once grain stocks are used up, families must still find food sources to last for 9-10 months of the year. Most families do maintain a small number of sheep and goats, ranging from a minimum of 3-4 up to a dozen for the more prosperous groups. By their own analysis, the fattening of even one sheep is of more use than the cultivation of a field: the proceeds from the sale of one animal can generally purchase from $50-100 \mathrm{~kg}$ of grain. Nevertheless the contribution of these small animals to household food security, while appreciated, is constrained by the factors outlined above, including difficulties in producing the capital to invest in animals, difficulties in maintaining herd size (animals that must walk up to two hours to pastures have observably lower fertility rates and milk production according to the herder who maintains the village's animals during the rainy season), and poor pasture conditions.

The remainder of the household grains must be supplied by a variety of diverse off-farm activities. There are very few remunerative activities in the surrounding areas. Some people can earn small sums from the transport of water or construction of mud bricks but other activities that were practiced in the past have largely disappeared due to the deterioration of the natural resource base. In the past people harvested a variety of tree products, such as gum Arabic and local fruits, and earned money from the sale of wood and charcoal. Most of the trees that supplied such products no longer exist. Those trees that have not been cut, largely due to their size or inappropriateness for charcoal production (e.g. baobab and tamarind), produce only small amounts of fruit compared to what they produced in the past when rainfall was higher. The only option now is for able bodied people to migrate outside the village for at least six months each year. The seasonal migration has two advantages: (1) there are fewer mouths to feed in the household when most adults are absent and (2) the travelers can sometimes send money, or goods in kind, back to the village to supplement what is available locally.

Up until now we have focused principally on the problem of grain supply. Given the problems families encounter in Teud Bitty for even these most basic needs, this would seem to be a fair proxy for food security in general. There are also several household financial issues that particularly concern women, however. In the past, it should be noted, that the provision of the staple cereal was the responsibility of male family members. In principle, this practice still exists, but in fact much of the burden has been shifted, whether directly or indirectly, onto women. In terms of their direct contribution, when there is a shortage of food, anyone who can participate does so. When women outmigrate seasonally in search of employment, the remittances they send back to the village are used to pay for food during periods of shortage. At least some of the women who leave the village go to Richard Toll where they work on harvesting and, in some cases, gleaning the rice fields of the industrial plantations. After meeting their own immediate needs, the rice they collect is returned to the village.

Indirectly, too, women contribute to the provision of grains through the money they pay to men for various services rendered. The most notable example of this is the money 
paid by women to men for the transport of water for household needs. At the cost of $600 \mathrm{cfa}$, a barrel of water used for cooking, drinking, and bathing may only last the family for 2-3 days. This means that the water costs borne by women in the family may average as much as $6-10,000 \mathrm{cfa}(\$ 12-\$ 20)$ per month. Some portion of this goes to pay the water fee at Niassene and the real costs of transport (nourishing the animal, repairing the cart, etc.). Another portion is profit for the transporter, a village male who most likely uses the proceeds to purchase grains.

One woman estimated that approximately $1 / 3$ of her revenues went for the direct purchase of rice. The other $2 / 3$ was divided approximately equally between the purchase of sugar, oil, clothing (for her children and herself) and water. Discussions with other women suggested that the portion of women's income devoted to water purchases may be even higher than this in many cases. In addition, since there are virtually no trees remaining in the territory, women are also obliged to pay for firewood, an expense that can reach 2-3000 cfa per month.

\section{Lack of Integration in the Production System}

The production system in Teud Bitty has been heavily oriented around natural resource based activities. People have grown crops, exploited trees for multiple purposes, and raised animals. Yet there is little integration between these activities and each element of the production system is essentially extractive. There are currently no systematic practices for maintaining the fertility of the soils or slowing their inexorable deterioration. Especially in the past, the cultivation of significant tracts of peanuts, which left the soils denuded and subject to wind erosion for more than half the year, contributed greatly to the reduction of soil fertility as experienced by the residents. As trees have been cut, there is no longer leaf litter to replenish soil nutrients. In the past farmers made "fertilization contracts" with pastoralist herders. The animals would be staked on particular fields at night in order to assure sufficient manuring of the fields. This practice has been abandoned because, with reductions in rainfall, it is no longer sure that precipitation will be high enough to capitalize on the manure. In years of very poor rainfall, fields which are not heavily fertilized produce better than those that are intensively manured.

With the progressive deterioration of agriculture, farmers turned next to tree products to meet their needs. Here too, the approach was essentially extractive. Tree cutting for charcoal and commercial wood sales took place without concern for other productive assets that the trees might produce or for the more general effect that their absence would have on the environment. Two or three farmers have systematically attempted to protect the trees on their fields but the vast majority have, at the least, freely permitted the anarchic cutting of trees and, in many cases, participated in the cutting themselves in order to make charcoal that could be sold to buy food grains.

Neither is the production of animals integrated in any but the most superficial way into the rest of the system. While there is some spreading of manure onto the tooker fields, 
the amounts available are too little to have much impact. The production of animal products (both meat and milk) is limited because grazing issues have never been resolved even though the size of the territory now vastly surpasses the requirements of the inhabitants remaining in the village and there are many vacant areas that could be organized into collective grazing areas. Herd size is generally too small to permit sustainable management of the animal population. Animals are thus little more than an appendage to the production system.

The livelihood system has deteriorated to the point where each activity is a desperate attempt to squeeze what little remains from the depleted resource base. The population knows that current livelihood strategies -- to the extent that they are based on the resources of Teud Bitty -- are essentially unviable. The future promises even greater outmigration of the population. The chief perhaps best expressed the current reality as he commented on the outmigration rows of the historical matrix. "If you see that we are few remaining here now, we are afraid that even these last ones will soon have to leave too." The situation has now gotten so bad that it is difficult to imagine its reversal. While in principle it would be possible to put strategies in place to facilitate the regeneration of the environment and to adapt the livelihood strategies to incorporate more sustainable activities (see case study in Part II), in fact this would be a monumentally difficult undertaking. Current resources are devoted almost entirely to addressing immediate food security issues, with little left over for investment. The dispersal of the most active members of the population makes it difficult to engage in coordinated reflection and planning, or to invest time and resources in development and resource management activities that might change the current situation.

The population's principal complaint is the shortage of potable water which, it is true, aggravates all the other problems of resource productivity and social relations. But, solving the water problem will do little to resolve the more fundamental issue of a natural resource based production system that has depleted virtually all of the productive resources in the territory.

The situation in Teud Bitty is grim indeed. The territory is little better than an environmental wasteland. The population is engaged in a perpetual struggle to assure their basic requirements of food, fuel, water, and financial stability.

In light of this sobering image, it was all the more astonishing to find, only five kilometers away, a community where the environment is healthy, the production system is apparently sustainable, and security of food and the basic necessities of life is not a matter that provokes particular anxiety or concern. We turn now to explore the situation in the neighboring territory of Maka Ndandary. 


\section{PART II: CASE STUDY OF MAKA NDANDARY}

\section{The Community of Maka}

The casual passerby would hardly know to stop in Maka Ndandary or even realize that they had happened on a community. There is no central square or meeting place and no collection of dense habitations to indicate the presence of an organized settlement. Driving by, one notes the occasional grouping of a few straw huts, usually with an animal enclosure immediately adjacent. In the distance, one may barely be able to see another grouping of straw huts but one would be hard pressed to identify these scattered hamlets, hardly visible from one to the next, as a village in the classic sense of that term. Indeed, because it doesn't fit our preconceived notions of what a village is, it may be better to use the term the inhabitants themselves use for their space: the hurum, or that which is "ours.

The scattered and apparently haphazard layout of the Maka residences belies its strong sense of community. Largely invisible to the outsider -- there is no village chief or other titled person with official standing at the head of the community -- one must dig deeper to find the compelling evidence of a community that has organized itself largely in response to the need to protect and maintain its natural resources.

The residents of Maka Ndandary are Pulaars from the wodaabe (jasarnaabe) lineage. The first four families settled together in the area in the middle part of the 19th century. They were joined in about 1900 by a fifth family. The descendants of these five families now comprise most of the inhabitants of the village, though as the families have grown over time, they have fractured into individual households. There are currently 15 household groups in Maka and the total population is estimated to be between 150 and 200 individuals.

The livelihood of Maka has traditionally been oriented around pastoralism: the production of cattle, sheep, and goats on extensive pasture lands. Traditionally this livelihood strategy has been based at least partly on transhumance: seasonal migrations to take advantage of better pastures and greater availability of water. We shall see that while this continues to remain an important part of the pastoralist production system in Maka, transhumance practices have undergone some significant changes over the past decades. In addition to raising animals, each family in Maka cultivates a small area, principally for the production of cereal crops.

The social organization of Maka is entirely informal. It is based not on any systematic selection of leaders, but rather the emergence of people, who by virtue of their personal initiative and effectiveness demonstrate their leadership and galvanize the respect of their neighbors. Anyone in Maka can tell you who these leaders are, even though they are given no official title and have no clearly defined responsibilities. The people who 
seem to have risen to be the most highly respected leaders are those who have demonstrated their willingness to take personal responsibility for protecting the common resources of the territory. There are three people who play this role most actively. An individual's leadership status is linked neither to his wealth nor social standing as a member of the founding family. Indeed, the person who acts in most cases as the representative of the village in diverse functions (whether actively surveying the forest to keep out poachers, negotiating conflicts with neighboring villages, or interacting with the authorities) does not belong to one of the four founding families and is among the three poorest families in the village. Furthermore, he owns no cattle. None of this appears to diminish the respect he has earned by virtue of his civic activities.

This apparent lack of formal organization was at first both perplexing and vexing to our outside research team which was used to the more classic village systems of organization around a chief and clearly identified elders. As we began to understand it better, however, we were struck by several notable strengths of such a system. It appears to be highly adapted to a society where people are often on the move with their animals and may spend relatively little time in the home community. If a leader is gone, it is up to those who remain to take responsibility for problems as they arise, rather than shunning responsibility because they may have no formal title or function. Furthermore, leaders are implicitly given authority due to their competence and effectiveness.

Leaders are those who are respected rather than the more common formula in rural Senegal which attributes leadership according to some characteristic such as age or social status, and then expects respect automatically to follow. And, what struck the team most strongly was that this leadership system is effective. In the section on managing territorial resources, there are numerous examples of how, when the need has arisen, the community has successful risen to the challenge of organizing a complex and effective social response.

The limits of this informal leadership system are felt most strongly when the hurum interacts with outside authorities who neither understand nor respect the informal leadership system as practiced by the hurum. They are much more familiar with the system which formally designates a chief according to some clearly defined formula and they are accustomed to directing their attentions to this individual who acts as the intermediary between the authorities and the village. In the hurum, as discussed above, there is no one individual who performs this function and, in the absence of one leader, another can as well take his place. One consequence is that the authorities, not knowing whom to address, often simply ignore the hurum in their activities. A second is that the absence of a titled leader reinforces the authorities' tendency (discussed further below in the explanation of territory) to dismiss these pastoralist communities as ad hoc groups with no social or geographical identity.

There is evidence that in response to external pressures or perceived incentives, the hurum is beginning to put more formal structures in place. These include a Women's Group, with its president, a less active Men's Group, and a designated representative of the Political Party. At the moment none of these organizations are particularly active 
and they appear to respond more to the needs of outsiders than to the concerns of the local population. The political representative, for example, is called only when the authorities -- or a neighboring village -- need to put on an impressive showing. They expect the Maka representative to mobilize the residents of the hurum and to strengthen the representation in a neighboring village when the authorities pass through.

\section{The Natural Resources of Hurum Maka Ndandary}

The next section will address the issue of resource management in Maka. This section simply presents an introduction to the resources that are presently found in the area. The present territory of Maka comprises approximately 2400 hectares of land covering an ellipse that is roughly eight kilometers long (east-west) and three kilometers wide (north-south). Soils of the territory are mostly a mix of sand and clay with some areas more clay (where water collects) and some spots noticeably more sandy.

\section{Water Resources}

As in Teud Bitty, water is a matter of grave concern. There are two shallow watering holes in the territory which maintain water for two to two and a half months each year during the wet season. The watering holes outside the territory are larger and hold water for somewhat longer, but they are becoming less accessible each year due to the incursions of crop land. One important water point on the east side of the hurum has been cut off entirely by neighboring villages' fields.

In addition to these watering holes, the local population digs traditional wells each year. These wells are about 12 meters deep and groups of households dig them together in central areas where they will be accessible to all. There are five such wells in the hurum. Salinization of the water from these artisanal wells is a major problem. The population has found that if they dig shallower wells, the water is less saline and can be consumed by humans. The shallowness of the well limits the amount of water that is available, however, and they can only pull five or six basins (30 liters each) at a time before they have to wait for the well to replenish. They can dig deeper wells from which they pull water for their animals. The water in these deeper wells is quite saline; the animals will drink it but the herders are convinced that the animals put on considerably less weight than if they were to drink a purer water.

\section{Trees and Grasses}

There are currently about 15 tree species found in the Maka territory. This is far less than what was found in the past (the population estimates that in 1945 there were as many as 50 different species in the area), but considerably more than what is to be found in neighboring agricultural villages. Spiny varieties dominate, with the principal 
species being acacia tortilus, balanites aegyptiaca, and ziziphus Mauritania. All three of these species are highly useful as fodder. Other somewhat less common varieties include adansonia digitalis (baobab), tamarindus indica (tamarind), acacia senegal (gum Arabic) and sclerocarya birrea. The principal bushy species are jatropha chevalerii, boscia senegalensis and adenium obesum.

The density of the trees varies across the territory and depends primarily on two factors. The first is how the land has been used over the past 20 years and the second is the ability of the population to control the cutting of wood in a given area. Casual observation reveals three different zones with clearly different tree densities. The most dense concentrations of trees are found in the central part of the village on the hurum gese (roughly equivalent to inner fields and pastures) lands. This is about $1 / 3$ of the territory and it is covered by what can be considered (for northern Senegal) to be a high concentration of trees. A second part of the territory (the "small" hurum ladde or outer pastures) also has quite a few trees but fewer than the hurum gese. Finally, the grand hurum gese which extends some six kilometers to the south-east of the hurum has trees but considerably fewer than the other two zones. This is because these lands were, until 20 years ago, cultivated by Wolofs and only entered the Maka territory after having been completely denuded of trees. While there is some natural regeneration that has taken place, this has been limited by the continued cutting of wood due to the difficulties Maka has in surveying lands on the outer limits of their territory (see Photo 2). This issue will be taken up in greater detail below.

The grass species in the territory are primarily fine gramineae species and are dominated by the species shoenfeldia gracilis. These plants are highly rich in nitrogen during the rainy season but their nutritional value diminishes rapidly thereafter. To maintain the health of their animals, the pastoralists thus employ a number of strategies to supplement the grass diet, including feeding tree leaves to the animals, transhuming to areas with different grasses providing more diverse nutrients, and pasturing their animals on the residues of harvested fields which are more nutritious than the grasses during the long dry season.

In the next section we look in greater detail at the livelihood system of the residents of Maka before turning to better understand how, on the macro level, they manage the resources of their territory.

\section{Resource Management at the Household Level: Livelihood Strategies in Maka Ndandary}

The population of Maka consider themselves first and foremost to be pastoralists by profession, though all cultivate a certain amount of crops. In short, animal raising is for all but the poorest families the principal element of the livelihood strategy, with field 
crop cultivation for most a secondary element (see Wealth Ranking - Figure 5). In fact, as this analysis will show, the two systems are very much in equilibrium and the production systems for animals and crops are both highly integrated with one another and ultimately dependent on the health of the wooded pasture lands.

Each household has a portion of land known as the hurum gese. On this land they construct their houses, made of millet stalk and straw, build enclosures for their animals, and plant their crops in fields that are surrounded by hedges. The land in the hurum gese that is not otherwise occupied serves as near-by pasture for young animals too small to be driven to the large pasture areas.

\section{Livestock Management}

For most families in the village, livestock consists of cattle, sheep, and goats. Herd size for cattle ranges from 0 (only two families) to 60 with the average herd size being about 25 . The number of sheep per family varies from 10 to 80 , with the average being 30 40 , while most families have somewhat fewer goats. Goat herds range from 10-35 with the average being about 20 in most cases. Our estimates suggest that the total herd size for the hurum is on the order of 335 cattle, 430 sheep, and 225 goats. All except two families have at least one horse or donkey to be used for animal traction.

All the animals, except when on transhumance, spend the night in the hurum gese in close proximity to their owners' houses. In the past, the animals were staked in a systematic pattern to ensure the maximum fertilization of fields that were to be cultivated the following year. This practice was abandoned in the mid 1980s since, with reduced rainfall the farmers found that crops produced less well unless there was at least a minimum level of precipitation which was increasingly rare. The animals continue to fertilize the hurum gese each night but less intensively than in the past when they were staked on one spot for ten or more days at a time.

All animals spend the rainy season (except in catastrophic years) in Maka. Many also spend most of the dry season in the Maka hurum and the fields of surrounding villages where they circulate during the dry season after the fields have been harvested. They leave the area, with a herder from the family, only when pastures in the Maka area are insufficient. It is more likely that large herds will leave than the smaller ones but in times when rainfall is inadequate or pastures are otherwise insufficient, the animals will 


\section{Wealth Classification of Families by Animals Owned Maka Ndandary}

\begin{tabular}{|l|c|c|c|c|}
\hline & & Cattle & Sheep & Goats \\
\hline & & 60 & 80 & 08 \\
\hline I. Rich & & 50 & 40 & 20 \\
\hline & & 40 & 50 & 05 \\
\hline & & 30 & 30 & 10 \\
\hline II. Average & sample & 32 & 15 & 25 \\
\hline & & 25 & 30 & 20 \\
\hline & & 20 & 40 & 20 \\
\hline & & 20 & 30 & 35 \\
\hline III. Poor & & 13 & 45 & 20 \\
\hline & & 05 & 10 & 15 \\
\hline & & 05 & 10 & 08 \\
\hline & & 03 & 10 & 07 \\
\hline IV. Very Poor & & -- & 10 & 10 \\
\hline TOTAL & & -- & 10 & 10 \\
\hline
\end{tabular}

This wealth ranking was carried out with one individual with whom the team had developed a close rapport. The informant was among the poorest in the village. Each line represents the animal ownership of one family. It was verified by in-depth interviews with three sample families in the "medium", "poor", and "very poor" categories.

Figure 5. 
all be herded towards more promising areas which are generally further south. In the past, the classified forest of Mbegué was one of the favored destinations for Maka herders since it was one of the few large grazing areas in the heart of the peanut basin. In 1991 most of the forest was given over to Mouride religious leaders; the trees were cut and the area was transformed into peanut fields. Since then, Maka herders have been obliged to go further in search of dry season pastures, often as far as Kaffrine.

The system of transhumance has changed significantly over the past 20 years...for the human population. For animals, there is little difference in most cases. In the past when cattle went on transhumance the entire family left with them, moving all their household possessions and generally staying away for the entire rainy season. Now, for reasons that will be discussed in greater length below, at least a few members of the family remain behind in Maka when the animals leave with one or several herders. If the transhumance is to be a short one, often only the young accompany the animals. If a longer journey is anticipated, the women may stay behind while the men guide the herd. While cattle, sheep, and goats all transhume together, some small animals will be left behind with the family members remaining in Maka since these animals assure their food security over the dry season.

The cutting of branches for livestock is generally frowned upon in Maka because of its potentially negative impact on the trees of the territory. Nevertheless, the lopping of branches for animal feed remains an important part of animal nutrition, particularly for those animals that stay in the area throughout the year and require supplements to the fine gramineae species that dominate the Maka pastures. Cutting does take place but is guided by norms intended to protect the trees from over exploitation. Especially in the hurum gese, the trees have impressive canopies that provide ample evidence that people take the restrictions on lopping seriously. There was evidence of more severe lopping in the outer pastures where the cutting by both local residents and outsiders is more difficult to control.

\section{Crop Cultivation}

The nightly deposits of animal manure in the hurum gese makes these lands particularly fertile. Families generally rotate their fields after five years, switching back and forth between two sites on either side of the gese. If either of these sites is not sufficiently fertile, they can always create a new field since fertile lands are not in shortage in the hurum gese, but it is generally easier to use the same fenced areas which have regained their fertility after a five year fallow. The principal crop is millet. In addition, most families cultivate small quantities of niebe, watermelon, hibiscus, melon, squash, and a very small amount of peanuts. These latter serve principally as condiments for home consumption and it is very rare that any of the harvest is sold. On these rich, well manured soils yields are impressively high. Estimates of average yields for millet were on the order of $3-400 \mathrm{~kg}$ per hectare, considerably higher than the average $(240 \mathrm{~kg})$ for the Keur Momar Sarr arrondissement 
The amount of land that a family cultivates depends primarily on their need to produce crops for food security and the availability of labor. Families with more animals tend to produce fewer crops, both because they need to produce less grains in order to eat (they can sell animals when the need arises) and because their animals require greater care and there is less labor available for food crop production. Poor families cultivate their land more intensively, using more labor intensive agricultural practices (such as multiple ploughing) that result in higher yields. One of the poorest families, which owns no cattle, cultivates about four hectares of land and, in an average year, can produce 1500 to $2000 \mathrm{~kg}$ of millet which lasts the family for nearly all of the dry season. Their lands remain fertile because the cattle of neighbors (usually relatives) graze and pass the night on their hurum gese. Families in the middle wealth category reported growing enough grains to feed themselves for four months, in one case, and 5-6 months (in an average year) in the second case.

\section{Food Security}

Families in Maka provide for their food security with a combination of crops and sale of animals. Small animals also provide for other diverse household expenditures, including payment of taxes, purchase of clothing, and medical expenses. These small, regular expenses are covered by the sale of sheep and goats throughout the year. Sheep and goats serve essentially the same purpose in the household economy: they are the family's "current account" from which people draw to cover their recurrent expenses. Most families seem to try to manage a herd of about 50 animals (divided between sheep and goats) for this purpose. The actual numbers in the herd may vary throughout the year as savings are drawn down and then reconstituted but a well managed herd will generally not decrease below 20-30 animals. One way of maintaining the size of the herd is for the owner to sell a mature animal and buy a very young one. The profit from this transaction is then used to purchase food or other needs. Reconstitution also takes place through natural procreation in the herd and by occasional investments in additional animals.

For most families, cattle serve as the financial reserve and are generally only sold in the case of a major family crisis or when recurrent expenses cannot be met by the sale of small animals. These sales are relatively rare, in comparison with the almost weekly sale of a sheep or goat in many families. One family (in the third wealth category) reported not having sold cattle in eight years, while another (at the top of the second wealth category) puts much less effort into crop production (cultivating less than a hectare) but had sold several cattle in the previous year.

The following describes a typical pattern in an "average" family's management of household resources to assure their food security. (This is indicative of how families manage their resources and is based on in-depth interviews with one family. There are certain to be differences among families.) The family compound (wuro) consists of the family patriarch and his two wives, three married sons with their three wives, two teenage daughters (not yet married) and a number of smaller children. The family 
cultivates a large field, surrounded by a live fence, which is subdivided into portions for the father and each of the sons. Each of them in turn allocates a portion of their field to their wives.

The family estimates that from the food produced in this field (none of which is sold) they can meet their household food needs for, on average 5-6 months out of the year. Generally by the end of the fifth month they will begin supplementing their own harvest with purchased food supplies. Once it becomes necessary to buy food, the family averages the sale of one sheep or goat per week. A sheep sells for 10-20,000 cfa per animal and can be exchanged for $50-100 \mathrm{~kg}$ or rice. The family consumes somewhat over $50 \mathrm{~kg}$ of rice every two weeks. A goat can be sold for 5-15,000 cfa.

Since the family owns 40 sheep and something over 25 goats, they can "afford" to sell an animal every week during 6-7 months of the year without serious depleting their stock beyond its capacity to regenerate by natural births. Over the past ten years, the number of sheep has been reduced by as much as half after sales during the dry season, but has never gone lower than ten while goats have never been reduced to less than 20 and have at times gone much higher (up to 50) than the 25 they are now. This particular family did not sell any cattle during the last decade. In the previous decade they lost six cattle during the drought and are still trying to rebuild their herd. They are now at a low point of eight adult bovines and five calves. This particular family, with a relatively small herd has not gone on transhumance at all during the last ten years.

Outmigration out of economic necessity is almost nonexistent in Maka. Occasionally, young men do leave the village in order to go to the city for a few months or to find work along the Senegal River. In nearly all cases their departure is provoked more by curiosity than by need. The money they make is generally used for personal consumer products (often a radio or new boubou) or is invested in small animals.

Having introduced the people and natural resources of Maka Ndandary, the next section looks at the strategies the population uses to manage the resources of the territory and how that interfaces with actions of the government and neighboring villages.

\section{Maka's Management of Resources at the Territoria! Level}

The management practices in the Maka hurum have evolved progressively over the past 50 years, with the rate of change accelerating dramatically from the 1970 s on when environmental and human pressures on the territory began to increase significantly. In order to understand the changes that have taken place, it will help to define some terms related to territorial management. 
As used in Maka (these terms may have slightly different meanings in different communities) hurum is a general term that describes the entire zone of security or surveillance of the Maka community. This term roughly approximates the words "terroir" in french and "territory" in English when those terms are used to describe the area that (from its own perspective) is under the control or management of a given community. The hurum is subdivided into two parts: the hurum gese and the hurum ladde. The wuro is a social unit that describes the household: people who are close relatives and live together in close proximity. In Maka the wuro are comprised of a group of straw houses grouped together; with considerable distance from it to the next wuro (see Photo 3). The hurum gese is the area immediately surrounding the wuro and it is considered to be the property of the wuro. The hurum ladde is a common property that, from the perspective of the local population, belongs to the community of Maka Ndandary. This view is not necessarily shared by either the neighbors of Maka or the state, as we shall see below, which is a source of considerable conflict.

\section{Delimitation of the Hurum}

In the past, the notions of hurum ladde and hurum gese were quite fluid. The Maka community has been based in its current location for close to 150 years but for most of that time, the limits of the hurum were not clearly defined (see Historical Profile - Figure 6 ). The pastoralists would move in and out of the area on a seasonal basis, always coming back to the same general area during the rainy season but their grazing area was essentially wherever they found convenient pastures and did not risk conflicts with others. This is in marked contrast to the Wolof definition of territory, which in most cases was the first action when a village took up a new location. Land would be burned, trees cut, or the authorities called to ride a horse around the territorial limits; in any case, the boundaries were nearly always clearly established from the start.

As recounted by a Maka resident who participated in the process, in 1956 the Maka pastoralists became concerned about the devastation of trees that they observed in the areas where they pastured their animals. They noticed that charcoal makers were coming into the area and beginning to wreck havoc on the vegetation and that fires were raging out of control on pastures that they needed. They also realized that they had no basis on which to stop these incursions since they had no boundaries around a territory they could call their own. The heads of family gathered together to discuss the problem and sent out a delegation to identify trees that would henceforth define the boundaries of the hurum of Maka. In defining the area that would become their territory, they followed two major criteria. The first was to avoid conflicts with the existing inhabitants and to do nothing that could appear as an aggressive act to their neighbors. The second was to define the lands that they actually used and could have some hope of successfully monitoring. The most distant limit was set at about seven $\mathrm{kms}$ from the 
c. 1850 First four families arrive in Maka

$1900 \quad$ Ly family joins Maka

$1945 \quad$ Famine

$1949 \quad$ Good Harvests

Fatal Epidemic

1953/4 Famine (less severe than 1945)

$1956 \quad$ Hurum territorial boundaries defined by residents

1970 Appeal to authorities to protect territory against incursion by neighboring village's fields; judgement in favor of Maka but not enforced

$1973 \quad$ Drought

1975 Mbaré leaves zone, Maka redefines territory to incorporate some of Mbaré lands

Hurum gesse sites fixed

Start of more rigorous surveillance of territory

Start of practice to leave part of family in territory when others leave on transhumance

1979 Demba Sow family joins village under new rules of installation

1985 Practice of parcage on hurum gesse abandoned due to decrease in rainfall

1991/2 Appeal to the Community Council concerning aggression of neighboring villages' fields in their territory; same result as in 1970

Forest fire coming from Lac de Gueir halted by local population

This historical profile was conducted with three senior men. It was conducted as a semi-structured interview and then compiled into the profile and verified with the population at large during the restitution.

Figure 6. 
inhabited part of the village because this was the distance that animals could comfortably cover in a day's walk and still return to the village by nightfall. Using these criteria, the delegation identified boundaries that went up to (but stopped short of the lands cultivated by Niassene and Teud Bitty on the south and west sides. The territory was larger to the east, but was limited there as well by the cultivated fields of Mbare. To the north they defined a major area leading up to two significant watering holes that were shared by several different groups in the area.

According to the our Maka informants (we were not able to confirm this through any other sources) Maka was the first Pulaar community in the area to define its territory in this way. Word quickly spread, however, and others followed their lead. We were told (but again could not confirm) that currently all the apparently vacant land from Maka west to the waalo of the Lac de Guier is delimited by various pastoral communities living in the zone.

Within the hurum, the definition of the hurum gese has also been made much more precise as the need to protect rights and space has increased. In earlier times, the concept of hurum gese was also highly fluid and there were no particular boundaries defining these spaces. When families left on transhumance, they would pack up all their belongings and move away for the duration of the dry season, returning only when they heard that the first rains had fallen in Maka. While they would return to the same general area, they would not necessarily settle in the same particular spot. Hence, the hurum gese of any particular family could move from year to year. Some families might stay and others go, but the community would regroup during the rainy season.

During the droughts of the early 1970s, the situation in Maka and the rest of northern Senegal was so severe that the entire population had to leave Maka and head south. No one stayed behind because there was no way to survive in the area given the complete absence of harvests and the state of the pastures that caused the death of many animals. Times were equally rough for the cultivators in the area who not only did not harvest any crops those years, but were less prepared than the nomadic pastoralists to move their entire family out of the region. Many, out of desperation, turned to the production of charcoal in an attempt to earn something during these lean years.

When the Maka pastoralists returned to their territory after the rains returned, they were shocked to see the devastation that had taken place during their absence. Vast expanses of trees had been cut such that, in their own words, "we hardly recognized our own place". The denuded pastures and brutally exposed stumps once again galvanized the community into action. Over the next several years a series of measures were put into place to ensure that such destruction would never take place again. These measures form the backbone of Maka's resource management strategies today.

The first specific act was a decision to fix each family's hurum gese site, clearly defining 
its boundaries, and mandating that each wuro should return to the same site each year. The purpose of this was multifold: to more clearly establish their rights to protect the inner area of their territory and to make possible the more rigorous surveillance of the resources against outside incursion (see Maka map - Figure 7). The hurum gese are the most closely surveyed part of the territory since each family is looking out for their own resources. Outsiders and insiders alike agree that no one would dare cut a tree within the hurum gese. The distribution of wuro permits a wider area to be controlled against incursion.

At the same time that the hurum gese were being defined and fixed, other measures were also put into place to increase the rigor of surveillance. The residents decided, for example, that they should abandon the practice of moving entire families out on transhumance. Instead, except in the most catastrophic of circumstances when staying put would jeopardize survival, at least a few members of the family would stay behind with the explicit function of protecting trees from outside woodcutters and charcoal makers. The decision was also made that if a family had to leave, others remaining behind would explicitly take over the responsibility of surveying the absent member's property. "If we didn't do this, they would come back and find not so much as a stick of wood on their property."

Another element of the strategy was to establish more rigorous criteria for accepting new inhabitants into the community. Previously, Maka -- like many other pastoral communities -- had an open door policy to newcomers, welcoming any and all who wanted to join the community. The devastation of the territory made the community aware not only of the damage being done by outsiders, but also the damage that their own residents were inflicting by careless or selfish use of resources. It was decided that only newcomers who agreed to the conservation strategies of the hurum would be welcome and that their activities would be carefully monitored until the other residents felt confident that the newcomers were adequately informed and fully respected the rules of the community. In 1979, a new family joined the Maka community under these rules. The community sent the more conservationist elders to spend the day with the new family on several occasions in order to better monitor their actions and ensure that they were not acting in ways inimical to the environment. 
++++ Former ternitorial Limits

Maka Ndandary

Trocks / roads (sand)

$\triangle$ Wuro (compounds)

DID seasonal ponds

* wells

N ${ }^{2}$

pressures on territory from neighboring villages

$\because$ hurum ladde (outer pastures)

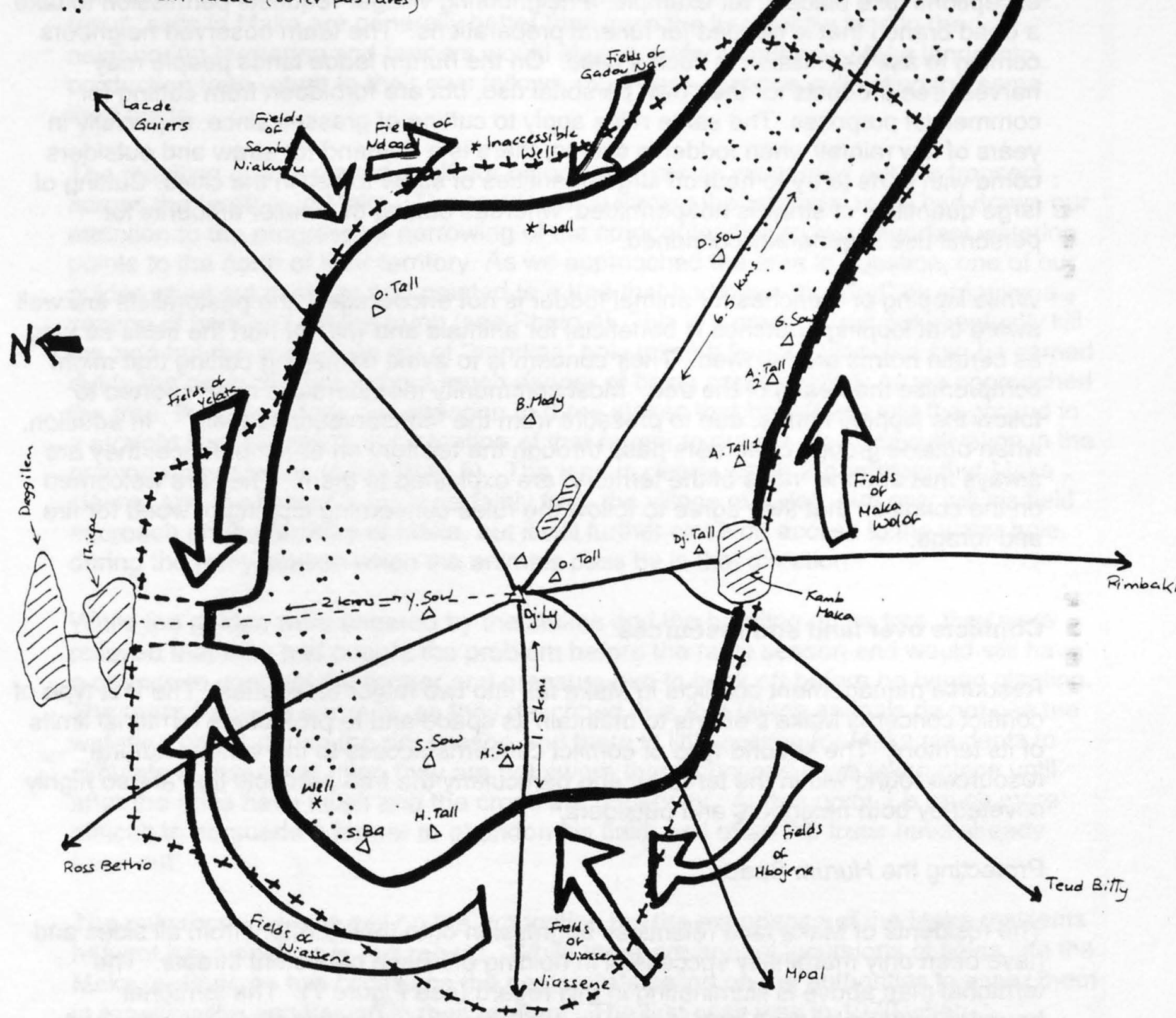

This map was prepared by 8 women and 15 men from different compounds. It was drawn on the ground, using ashes to designate boundaries, and sticks, leaves and stones to represent various landmarks. After completing the initial map showing the current boundaries of the hurum, the group was asked to redraw the boundaries to show what the hurum was like in 1970 . These older boundaries are represented by a dashed line. 
The community has established numerous rules concerning the use of natural resources in the hurum. These tend to be stricter in the hurum gese than in the hurum ladde, principally because control of access and use is more difficult in the outlying areas. In the hurum gese no cutting of any tree product, whether from live or dead trees, is permitted without the express permission of the land holder. Permission is almost never granted to cut the trees on these near pastures. Only the most occasional exceptions take place if, for example, a neighboring villager requests permission to take a dead branch that is needed for funeral preparations. The team observed neighbors coming to ask permission in such a case. On the hurum ladde lands people may harvest tree products for their own personal use, but are forbidden from cutting for commercial purposes. The same rules apply to cutting of grasses since, especially in years of low rainfall when fodder is scarce, there is a demand for straw and outsiders come with carts to try to haul off large quantities of straw to sell in the cities. Cutting of large quantities of straw is not permitted, whereas cutting of smaller amounts for personal use is generally condoned.

While lopping of branches for animal fodder is not encouraged, the pastoralists are well aware that lopping branches is beneficial for animals and will not hurt the trees as long as certain norms are followed. Their concern is to avoid damaging cutting that might compromise the health of the tree. Most community members are now reported to follow the lopping norms, due to pressure from the "conservation leaders" . In addition, when outside groups of herders pass through the territory on transhumance, they are always met and the "rules of the territory" are explained to them. They are welcomed on the condition that they agree to follow the rules concerning lopping of wood for fire and forage.

\section{Conflicts over land and resources}

Resource management conflicts in Maka fall into two major categories. The first type of conflict concerns Maka's efforts to maintain its space and to protect the territorial limits of its territory. The second type of conflict concerns access to the various natural resources found within the territory, and particularly the tree products that are so highly coveted by both neighbors and outsiders.

\section{Protecting the Hurum Space}

The residents of Maka face relentless aggression onto their territory from all sides and have been only marginally successful in holding off these persistent threats. The territorial map above is illuminating in this regard (see Figure 7). The territorial boundaries fixed by the Maka leaders in 1956 are shown on the map with a dashed line. The current boundaries are shown by the dark line, and the pressures today on the 
territory are shown with arrows. There is currently not a border that is safe from aggression, though the east side of the territory is under substantially less pressure than the other three directions.

Pressure on Maka land is a result of two factors. One might be called the "push effect" because conditions in the home territories of neighboring Wolof villages are pushing farmers to expand onto new lands as their own lands suffer a progressive loss of fertility over time. The second effect is the "pull" effect from the Maka territory where soils are particularly rich due to continued manuring and the maintenance of tree cover. As a result, soils in Maka are generally better than even the best fallow land in the neighboring territories and farmers would always prefer to put new Maka lands into production than return to their own fallows, much less continue cultivating the same tired fields.

The resulting drama played itself out before our eyes as we carried out our transect across the territory in Maka. The residents, in tracing the territorial map, had drawn our attention to the progressive narrowing of the corridor leading to two important watering points to the north of their territory. As we approached the area in question, one of our guides cried out in anger and pointed to a tree that had been "banded" by stripping a section of bark around the trunk (see Photo 4). This is a practice that will eventually kill the tree but the immediate act of "banding" only takes a few minutes and can be carried out in the dead of night without much danger of being apprehended. As we approached the tree, the guide drew our attention to three stakes that had driven into the ground in a straight line, indicating the intention of that farmer to put the land into cultivation in the coming rainy season (see Photo 5 ). The land is clearly within the territory that Maka claims, and the farmer is most certainly from the village of Yelet. Not only will his field encroach on the territory of Maka, but it will further close off access to the water hole during the rainy season when the animals pass by in that direction.

While the guides were angered by the stakes and the banding of the tree, they were relieved that they had caught the problem before the rainy season and would still have a chance to confront the farmer and pressure him to back off before he began planting. The more frequent scenario, as they described it, is that (since animals do not use the watering points during the dry season and there is little reason for Maka residents to circulate in that area) often they are not aware that incursions have taken place until after the rains have fallen and the crops are underway. At that point it is much more difficult to persuade a farmer to abandon his field, and often the trees have already been cut.

The only recourse is to call on the authorities but the experience of the Maka residents has not been positive in this regard. While there are annual incursions of fields into the Maka territory, on two occasions the pastoralists called on the authorities to assist them in repelling the aggression in their territory. The first case was in 1970 when representatives of the arrondissement came to the scene and the second was some twenty years later in 1991, by which time the communauté rurale structure was in place 
and the President of that structure came to the village. In both cases, the authorities ruled in favor of the Maka residents, saying that the placement of the fields would provoke numerous conflicts since there was not enough space for animals to pass by. The cultivators were requested to abandon their fields. But the victory was illusory. The cultivators did not retreat and the authorities did nothing to enforce their mandate, despite continued pressure from the Maka residents.

State Perspectives on Land Management in and around the Hurum. While in the two particular cases cited above, the State authorities did at least in theory recognize the rights of Maka residents, this was primarily in the perspective of avoiding conflict between two neighboring communities. In general the state has cast a blind eye on the extension of cultivated land onto the grazing areas of Pulaar hurum. In theory, there are two superimposed sets of rules regulating land management in the area. The first is the general land law that determines rights to land in rural areas. The guiding principle in the management of such lands is that they shall be allocated to those who will render them productive or, in french, "les mettre en valeur." The authority to make decisions on whether land is in productive use or not lies principally with the Rural Community Council and its President.

In the area where these two case studies take place, there is another rule in place that should take precedence over the general land law since the zone has been classified as a sylvo pastoral reserve. In theory, this means that pastoral activities are favored, that cultivation is to be limited to subsistence crops, and that the planting of peanuts is absolutely forbidden. Such lands are supposed to be administered by the Eaux et Forets, with no control by the Rural Council. In fact, there is no evidence that there is any application whatsoever of the sylvo-pastoral reserve regulations and the Rural Council acts as though its authority over lands in the reserve is identical to its authority over other lands under its purview.

While the Rural Council perceives its authority to be the same throughout the communaute rural the reality is that their attentions are much more heavily oriented towards the waalo lands around the lake where the demand for land is much higher and the potential for conflict much greater. While their interpretation of the law is that anyone who wants to increase their fields by "as much as a centimeter" is required to get authorization from the Rural Council, in fact they knowingly overlook field expansion taking place throughout the jeeri unless it provokes some major conflict and they are obligated to intervene to keep the peace.

Ultimately, the authorities' interpretation of the Land Law and their attitude towards pastoralists is critical in determining what rights Maka residents have in protecting their space. Our discussions with the authorities were not promising in this regard. In the first place, there is no understanding that there are clearly delimited pastoral territories, in the same way that cultivating communities have established village territories. The authorities systematically expressed their view that "herders go where there is no one 
else." And secondly, when it comes to considering land allocation, in the view of the authorities, productive use of land implies the production of crops or orchards.... and not the use of land to graze livestock. Livestock concerns are taken into consideration to the extent that the authorities want to avoid conflict between herder and farming populations. Therefore they are willing to delimit and somewhat enforce animal rightsof-way to watering points. But, the general principle remains that -- from their perspective -- crops are considered to be a more productive use of land than grazing. Therefore, the general extension of cropland in the zone is not considered by the authorities to be a matter of any concern. And, more particularly, the aggression into Maka territory is not considered to be an issue since, from the authorities point of view, Maka has no territory that they can be legally defended.

When confronted with the concerns of Maka residents and other pastoralists of the zone, the Rural Council President quickly dismissed the issue, saying that "less than $1 \%$ of the land in the sylvo-pastoral reserve has been put into cultivation" and therefore that the alleged problem was of no significance. In fact, recent Landsat photos suggest that the figure is closer to $19 \%$ and is increasing annually.

The authorities made it clear that they respond where the pressure is the loudest and that their major preoccupation is to avoid the escalation of conflict. In most cases, the farmers have been more insistent and forceful in expressing their concerns than the pastoralists have been and the State has more often responded in their favor. Even where the authorities have not actually intervened, both farmers and pastoralists perceive that the state would favor the farmers in the case of confrontation and that the herders would indeed back off when subjected to pressure. In short, in the Rural Community of Keur Momar Sarr, at least as far as the jeerilands are concerned, there is no real "management" of land. There are no plans for how land should be used in the area or what the rights of different populations and interest groups should be. Instead the Rural Council essentially "manages" conflict as it arises, with the principal objective being to reduce the number and severity of conflicts, regardless of whether the solutions put in place are equitable, or environmentally or socially sustainable.

Acting in this context which is characterized by aggression of neighbors and complicity and/or neglect by the authorities, Maka has been largely impotent in defending itself against the annual expansion of fields that have progressively compressed its territory. Attempts to strengthen the territorial defense have met with only limited success. On the west side, where the pressures (from Niassene) have been the strongest, one Maka resident has planted his field at the very limit of their territory, confronting field with field. They also maintain a high hedge along the western border to try to reinforce their property rights. And, there are indications that they are beginning to use the threat of conflict as an element of their defensive strategy.

Just last year a Niassene farmer jumped over the live fence separating the now contiguous territories to stake out a field in the hurum gese of a Maka herder. The herder happened to be on transhumance with his animals at the time, but his wife noticed what 
was happening and told the farmer in no uncertain terms to stop. The farmer refused, telling the wife to pass a message to her husband that he should move off "and go where the other herders are." The wife returned with her husband's brother who again warned off the Wolof and was again insulted in return. Finally, the elders of Maka demanded that the chief of Niassene meet them in the field to discuss the issue. A major meeting took place and "things got hot." The men of Maka warned the Niassene chief that if the field was cultivated, they would return with clubs if necessary to defend their land. in the face of this surprising display of resistance, the chief of Niassene backed down and told the farmer that he could not just unilaterally expand his field beyond the border but would have to negotiate with the herders involved. While the Maka residents sense that the "pressure is still there", they have observed no further actions to expand fields in that area since the meeting.

\section{Protecting the Trees and other Resources of the Territory}

While the Maka residents have had only limited success in protecting their space from aggression by neighboring farmers, they have been substantially more successful in protecting the non-land resources of their territory: most notably the trees that they consider to be an essential element of their livelihood system. The protection of these trees is ongoing battle, but one (unlike the protection of space) that they feel they are winning. This victory comes, however, at the cost of constant vigilance and almost daily confrontations that are required to enforce their conservation strategy against outside aggressors.

Surveillance of the territory takes place at several levels. The most rigorous and systematic is in the hurum gesse where each family takes the lead on controlling access and use of resources on their own landholdings. Because the gesse lands surround the inhabited compound of each family, surveillance is fairly straight forward and is a routine part of the daily activities of all family members. Cutting of a tree in the gesse is considered to be such a clear infraction of personal space that, in the words of one villager, "we have no need for discussion in these cases, we resort directly to aggression." Should a case arrive where an entire family leaves the territory on transhumance or other business, neighbors in the community will take over surveillance of their lands to ensure that others do not move in to devastate the resources during the holder's absence. We were able to verify that this practice actually takes place since, at the time of this study, the entire Demba Sow family was on transhumance and several others people noted that they passed regularly through his gesse lands to monitor activity there.

In the hurum ladde, surveillance is more difficult due to its distance from the inhabited village and the sizeable area of the land to be covered. In principle, everyone is responsible for surveying the hurum ladde. In practice, people take this responsibility with greater or lesser degrees of seriousness. There are some members of the community (the three "conservationists", in particular) who go out to the ladde with the express purpose of monitoring activities there and stopping any aggression. The more usual practice is for people to keep a watch out for tree cutting activities when their usual activities take them 
to the ladde. In either case, when someone sees illegal cutting taking place they approach the person, inform them that they are Maka land, and request that they immediately cease and desist in their activities.

As the density of trees has declined on surrounding Wolof lands, the pressure on the trees remaining in Maka has intensified. Fraudulent woodcutters are caught by community members in the ladde as often as several times a week. In our discussions, several people (men and women alike) reported on cases they themselves had encountered during the previous several weeks and the actions they had taken to give the person warning. While the community acknowledges that their surveillance is far from perfect and that incursions do continue to take place (especially in the more distant parts of the ladde), they note that when they confront someone who is cutting, the person almost always stops and leave the territory without creating further disturbances. They feel that this is due to their systematic insistence on their rights to control cutting over the last 20 years. At first their authority to regulate such activities was challenged. This often caused problems because the only recourse was for the hurum member to take the culprit to the Eaux et Forets agent and plead their case before the authorities. Given the distance to Keur Momar Sarr, this was an unwieldy process at best. In many cases, according to reports from Maka, the woodcutter would manage to "bargain" his fine away and escape with only the lightest penalties. "So, " they say, "the only solution now is for us to be our own Eaux et Forets." They now enforce compliance with their own brand of persuasion and, where necessary, threats.

As pressure on the ladde has become more intense, there appears to be a tendency toward a more systematic approach to surveillance of these lands as well. At the moment this is observed principally on the "minor ladde " to the north of the village. (The "major ladde" lies to the east.) The pressure on this land is particularly high due to its smaller area and proximity to neighboring villages as well as its accessibility to the residents of Maka themselves. The minor ladde also happens to lie nearly adjacent to the hurum gesse of one of the three self appointed conservationists of Maka, however. Since his animals use this ladde on a regular basis, he was keenly aware of the degradation that was taking place, especially to the trees on these lands. As a result, he decided to increase his surveillance of the area and to treat it (for surveillance purposes only) as if it were his own gesse, enforcing the most rigorous restrictions on the cutting of trees in this zone. While this area does not yet have as many trees as the gesse parts of the territory, it is notably more wooded than the "major" ladde and the effectiveness of the more systematic surveillance is immediately apparent.

Currently, the community feels that neighbors and passersby accept at least the principle that they have rights to control tree cutting on both gesse and ladde lands. Surveillance continues to be imperative, but once someone is caught they respect the order to stop. From the Maka perspective, conflict over tree cutting is thus considered to be an "issue" but not really a problem. The pastoralists effectiveness in controlling woodcutters was triangulated not only by observation of the density of trees in their territory in comparison 
to neighboring lands, but also by comments of villagers in neighboring territories. "Those trees belong to the Peul," reported one of our Teud Bitty guides as we came upon a more heavily wooded expanse during a transect that took us beyond the limits of their territory, "no one dares to cut so much as a branch...." This attitude toward trees was in clear contrast to outsiders' attitudes toward lands held by the pastoralists. The latter was best captured by the comments of Wolof farmer in the neighboring community of Maka Wolof: "where the Wolof expands his fields, the pastoralist will, quite simply, retreat."

\section{The Livelihood System and the Environment of Maka}

The pastoralist livelihood system as practiced in Maka Ndandary is essentially in harmony with its environment. The animal population remains well within the limits of what can be supported by the territory in all but the worst years of rainfall ${ }^{2}$, when (an anticipated part of the livelihood strategy) it is expected that the human and animal populations will move south to zones of higher rainfall. The grasslands of the territory are healthy and productive, benefiting both from manure deposits and hoof trampling which breaks up the hard surface of the soil. Cultivated areas have, by all accounts, maintained or improved their soil fertility. Tree cover, while variable across the territory, is noticeably more dense, more diverse, and more productive than in neighboring agricultural villages and there is clear evidence of natural regeneration particularly in the areas that are most rigorously surveyed by the local population. The pastoralists explain this in part by the dispersal of seeds by their animals.

The healthy interaction of the livelihood system and the environment can be explained by two related factors. The first is the essential integration of all elements of the production system. Animals, trees, and crops are all integrated such that no resource is subject to sustained extraction without having some compensating input. The second ingredient is the explicitly conservationist approach of the population which recognizes the extent to

${ }^{2}$ Calculations by the Centre de Suivie Ecologique which has conducted long term studies of biomass in Senegal suggest that the carrying capacity of grasslands such as those found around Maka are on the order of 3.2 ha per U.B.T. Other more conservative estimates have suggested that $4-5$ hectares would be required on these drylands. The total number of animals held in Maka at the time of our study translated into 382 UBT. Using CSE figures would suggest that, without seasonal outmigration, a territory of 1,222 ha could support the Maka animal population. The higher figures would require a larger area of $1600-2000$ ha. In either case, the animal population of Maka can be supported on their territory which covers approximately 2400 hectares. While this is theoretically possible, it should also be kept in mind, however, that the pastoral livelihood system does not attempt to maintain all activities within the territorial limits. In order to assure a diversity of grasses and to maintain access to water resources, herders count on using areas beyond the limits of their own territories, grazing on stubble fields of neighboring villages during the dry season, and out migrating entirely during periods of drought. Equally, it is anticipated that herders from other regions will use their territory under their own diversification strategies, subject only to the condition that they respect the conservation strategies of the local hurum. 
which their well-being depends on the integration of these different production systems and takes explicit steps to protect the resources from attacks whether by outsiders or by their own residents. As the pressure on resources has increased due to population increases, reduced rainfall, and other diverse factors, their strategies to protect them have becorne progressively more stringent and more systematic (see Historical Matrix - Figure 8).

The pastoralists' vulnerability is not at the hands of a degrading environment that lacks the resources to maintain the population but rather to their neighbors. The aggressive, expansive land use patterns of agricultural villages in proximity to Maka are currently threatening this sustainable, conservationist livelihood strategy that is uniquely suited to a region where rainfall is low and variable. Part III addresses the issue of land use patterns in the region and their impact on the environment. 


\begin{tabular}{|c|c|c|c|c|}
\hline & 1945 & 1970 & 1985 & Present \\
\hline Size of Hurum land area & $\because \because \therefore \quad 20$ & $\because \because \because \because 19$ & $\because \because \because 9$ & $\because \bullet$ \\
\hline Density of trees & $\because \because \because \because \quad 20$ & $\because \because \because \bullet 16$ & $\because$ & $\because$ \\
\hline $\begin{array}{l}\text { Biodiversity of tree } \\
\text { species }\end{array}$ & $\because 80 \because \because \bullet \bullet \bullet \bullet$ & $\because \because \because \because 80$ & $\because \because \cdots: 21$ & $\because \because \cdots \bullet 15$ \\
\hline $\begin{array}{l}\text { Quality of } \\
\text { grasslands/pastures }\end{array}$ & $\because 17$ & $\because \because \because 14$ & $\because \because \because \bullet 10$ & $\because \bullet \bullet$ \\
\hline Availability of water & & $\because \because \because \cdots 12$ & $\because \because 8$ & $\bullet \bullet \bullet$ \\
\hline $\begin{array}{l}\text { Grazing space available } \\
\text { per animal (in hurum) }\end{array}$ & & $\because \because \because 13$ & $\because \because \bullet 9$ & $\because \bullet \bullet$ \\
\hline $\begin{array}{l}\text { Human population of } \\
\text { hurum }\end{array}$ & $::: \bullet$ & $\because \because \cdots \cdots \bullet$ & $\because \because \because \bullet \bullet \bullet \bullet \bullet$ & $\because \because \because \because \bullet \bullet \bullet$ \\
\hline Number of conflicts & $\because \because \bullet$ & $\because \because \because \because 20$ & $\because \because \because: 18$ & $\because \because \because \because \because \because \because \otimes^{\prime}$ \\
\hline Number of Trees & $\because:: \because:$ & $\because \because \because 10$ & $\bullet \bullet$ & 1 \\
\hline $\begin{array}{l}\text { Biodiversity of Tree } \\
\text { Species }\end{array}$ & $\because \because \because 10$ & $\because \because \because 8$ & $\because \bullet$ & $\bullet$ \\
\hline
\end{tabular}

- Of the 46 beans under conflicts, these were further subivided to show 17 between cultivators and herders, 9 between different herders, and 20 with woodcutters attempting to cut trees in the hurum.

This historical matrix was carried out by three men and two very active women during the team's initial (preliminary) visit to Maka. The group was asked to compare their perceptions of what is happening in the Maka territory (the first eight variables) with what they observe on neighboring agricultural village territories (the last two variables). While they report a diminution of resources in their own territory, their assessment mirrored our own observation that the tree density and biodiversity remains significantly higher in Maka than in neighboring Wolof territories. 


\section{PART III: TEUD BITTY, MAKA, AND LAND USE PATTERNS IN THE SYLVO PASTORAL RESERVE OF PAL-MÉRINAGUÈNE.}

The territorial map of Maka Ndandary reflects the herder community's perception that they are being pressured from all sides as neighbors seek to expand their fields into the fertile pastoral territory. These pressures are evident from the maps taken from aerial and satellite photographs as well as from recent flyovers and videography of the region. Comparing the maps based on aerial photographs of 1954 and 1980 (see Figure 1), it is evident that villages such as Teud Bitty and Rimbakh significantly increased the area that they cultivate during this period, such that in the later photograph there is almost no remaining rangeland in the vicinity of these communities. Unfortunately, the coverage does not permit us to analyze with these photographs the changes around Maka (which does not appear on the earlier photo) but video transects passing north through Maka confirm the expansion of crop lands into previous grazing areas. These more recent aerial videos also confirm the significant loss of trees in the agricultural communities. Most areas that show up with scattered trees in the 1980 photo are now virtually devoid of trees.

The interpretation of the 1990 Landsat image (see Figure 2) also indicates the extent to which Maka is surrounded by agricultural communities. Ground truthing and aerial videography confirm that the situation has worsened since the time of the 1990 satellite image. The area north of Maka, for example, has now largely been filled in by cultivated lands.

The expansion of agriculture into the dry grasslands of northern Senegal makes little sense from either an economic or ecological point of view. The short-lived benefits of cultivating on pastoral lands are at the expense of the tree cover and soil fertility. Yields are subject to uncertain rains and rapidly diminish after the first year or two when the crops take advantage of residual manures. More worrisome yet, the expansion is at the expense of an economically viable and environmentally sustainable pastoral production system. The threat is exacerbated by the anarchic nature of the expansion. One of the pastoralists' biggest complaints is that fields do not expand by slow progression, but rather skip and jump across the pasture lands, effectively making a much greater footprint than the actual space that the fields occupy. The lands remaining between the fields, while not cultivated, are too small to permit cattle to pass without danger to the crops in neighboring areas. Both farmers and pastoralists describe this as an express strategy of the cultivators who stake out a certain expanse and then as the frontier field loses its fertility backtrack to fill in the intermediary spaces. Pastoralists are also threatened by the blockage of access routes to watering points. These corridors are often particularly coveted by farmers because over the years they have been intensively fertilized by animals as they approach the water sources. In Maka one important water point, to the east, has already been completely blocked by field encroachment, and another set of seasonal ponds to the north is on the verge of being encircled by fields that block access entirely. 
In short, the continued viability of the pastoral livelihood system as practiced in communities like Maka depends on

(1) maintaining a minimum area of contiguous territory containing diverse tree species and healthy grasslands

(2) protecting access to seasonal watering holes and passageways sufficiently wide to ensure that there is no danger of animal divagation into neighboring crop lands

assuring a network of interconnected passageways leading out of the zone and toward the south for use in times of rainfall shortages or when grass and/or sanitary conditions are otherwise unsuited for the animals in their home pastures

(4) maintaining common "insurance" pastures in areas further south that can be used in times of severe rainfall shortage in the north.

Current land management policies threaten all four of these prerequisites to maintaining the pastoral livelihood. Reforms in local and national land use policies are urgently needed to ensure the more rational and sustainable use of resources in such areas of limited and variable rainfall.

\section{Policy Implications}

\section{Community level}

Communities like Maka Ndandary need to become even more forceful and vigilant in protecting their interests. This recommendation in no way belittles the remarkable efforts they already have in place to protect the resources of their territory. But they themselves are aware that the current aggression is more sustained and more systematic than what they have had to deal with in the past. It was clear during our stay that the act of participating in an RRA that studied these issues was a galvanizing force for this community. One woman declared with great pride at the end of the study that "this map [the paper copy of the participatory map made by the community] is the identity card of our territory." She went on to exhort her friends and neighbors to use it in defending their interests before the authorities and when conflicts arose with cultivators. Pastoral populations like those in Maka have a tradition of retreating when aggressed. There is now no longer anywhere to retreat, however. As a result, their approach has to change to one of defending territory, space, and livelihood. While this process has already begun with the initiatives of the local population themselves, it needs to be reinforced and strengthened. The approach of the NGO ARED, which translates legal texts, case studies, and other informational pieces into Pulaar so that local populations can use the information to defend their own interests is an extremely useful approach in this context. Maka residents expressed an eagerness to participate in literacy classes and gain access to these types of information. 


\section{Rural Community Councils and local authorities}

Most local land allocation decisions that affect pastoral communities are made by the rural community councils. In many cases there is no overall land "plan" for the area they administer. Rather, decisions are made on an ad hoc basis according to political and other pressures and an attempt to avoid serious conflict between community members. Council members are taught to take land away from those who do not render it productive and to reallocate it to those who will do so. The definitions of "mettre en valeur" are anything but clear, however, and to date they have been nearly universally interpreted to favor crop production over extensive livestock. Where, as in the Keur Momar Sarr Rural Community, there are competing livelihood systems it is critical that there be representatives of various interests on the Council. Specific spaces should be allocated to representatives of groups practicing extensive livestock production. While the present president of the council is a Pulaar and a self-proclaimed representative of herder interests, in fact he has almost no knowledge of these traditional herding communities or their needs and concerns. Herder representatives members should be selected by the hurum themselves, just as sedentary agricultural villages are allocated slots on the council.

The Community Councils should after careful study and in close consultation with Rural Community members carefully identify the needs and concerns of different livelihood sectors within the community. From this they should draw up general land allocation guidelines that protect the interests of various groups. If, for example, there is a need to expand croplands, it should be done only in designated areas where it will not impinge on animal rights of way or the overall viability of the pastoral system.

\section{National}

On the national level there are several actions needed to maintain the viability of herding communities like Maka Ndandary. There is urgent need for national clarification of the meaning of "mettre en valeur" as it applies to land allocation and, especially, the need to recognize extensive livestock production as a valuable productive activity.

In addition, just as each Rural Community needs to define the concerns of various livelihood sectors, the same analysis needs to take place at the national level to ensure that access routes and southern pastures essential to the livestock system are maintained and protected from incursion.

While the threat to the environment and to the livelihoods of pastoralists is very real, it is not too late to put policies in place that can improve the situation and protect both resources and the economic interests that depend on them. Time is running out, however, and only by a concerted effort that mobilizes activists at the national, regional, and community level will the needed progress be made. It is hoped that these case studies and others like them will help to promote the reflection needed to (1) recognize the problem and (2) begin to take the necessary actions to solve it. The residents of Maka have not given 
up. And neither should others who share their concern for maintaining the fragile ecosystems of dryland northern Senegal. 


\section{Annex 1 \\ Program of RRA Field Work}

\section{Teud Bitty}

\section{Date}

Friday $1 / 19 / 96$

Saturday $1 / 20 / 96$
Sunday $1 / 21 / 96$
Monday $1 / 22 / 96$

Village Map

Transect

Historical Profile

Territorial Map

SSI (Community Land Mgmt)

Analyze Spatial Information

SSI (household resource mgmt)

SSI (household resource mgmt)

SSI (household resource mgmt)

SSI (herd management)

Tuesday 1/23/96 Vehicle Transect around territory

SSI

Wednesday $1 / 24 / 96$

Day in Maka Ndandary

Historical Matrix, map

Venn Diagram

Thursday 1/25/96 Historical Matrix

Preliminary Analysis

Friday $1 / 26 / 96$

\section{With Whom}

$50+$ men, 15 +women, 43 representatives of neighboring villages

25 men, 10 women

2 women, 4 men (working in three groups)

30 men, women

3 older men, 15 younger men

Village Chief

Team and several village men

4 women

3 women

3 women

Pulaar herder

3 men

Pulaar herder

(Half of RRA team)

3 Maka men, 2 Maka women

10 men, 5 women

3 old men, 3 women, 4 male youth

Older men

50 men/women 


\section{Maka Ndandary}

Date

Activity

Wednesday 2/14/96 Protocol

SSI (milk)

Hurum map

(Historical analysis)

SSI (Resource use rules)

Friday 2/16/96

Vehicle Transect

SSI

SSI

Saturday 2/17/96 Complete Vehicle Transect

SSI

Wealth Ranking

Historical Profile

Sunday $2 / 18 / 96$

Monday 2/19/96
SSI (average family)

SSI (wealthier family)

Wealth Ranking

SSI (poor family)

SSI (conflict)

Village Feedback

\section{With Whom}

6 men, women

3 women

8 women, 15 men

same as above

2 men, 1 woman

Eaux et Foret Agent in Keur Momar Sarr Rural Council President in KMS

2 men

Neighboring hurum family (Sare Alassane)

2 women

4 men, 2 women

2 men, 1 woman

2 men, 2 women

1 man

1 man

2 men

6 men, 4 women 


\section{Annex 2 \\ Glossary}

arrondissement

barlou

Eaux et Forets

hurum

hurum gesse

hurum ladde

jeeri

lacke

mettre en valeur

tooker

waalo

wuro an administrative jurisdiction, headed by a sous-prefet.

In Teud Bitty, the "small pasture": an area formerly reserved for grazing inside the territorial limits adjacent to the inhabited village

The Water and Forest Ministry and the agents of the State that regulate the use of these resources

In Maka, the community and the lands which it considers to be its own: "that which is ours"

In Maka, the inner pasture area that surrounds the inhabited part of the community

In Maka, the extensive outer pasture area at the periphery of the territory

The dryland savanna that does not flood

In Teud Bitty, the inner fields

To "render productive": key language in the national land law that determines the basis on which land will be allocated

In Teud Bitty, the small fields immediately adjacent to the inhabited part of the village: derived from the wolof toll keur or house fields

The lands adjacent to the lake that flood seasonally

In Maka, the family compound 


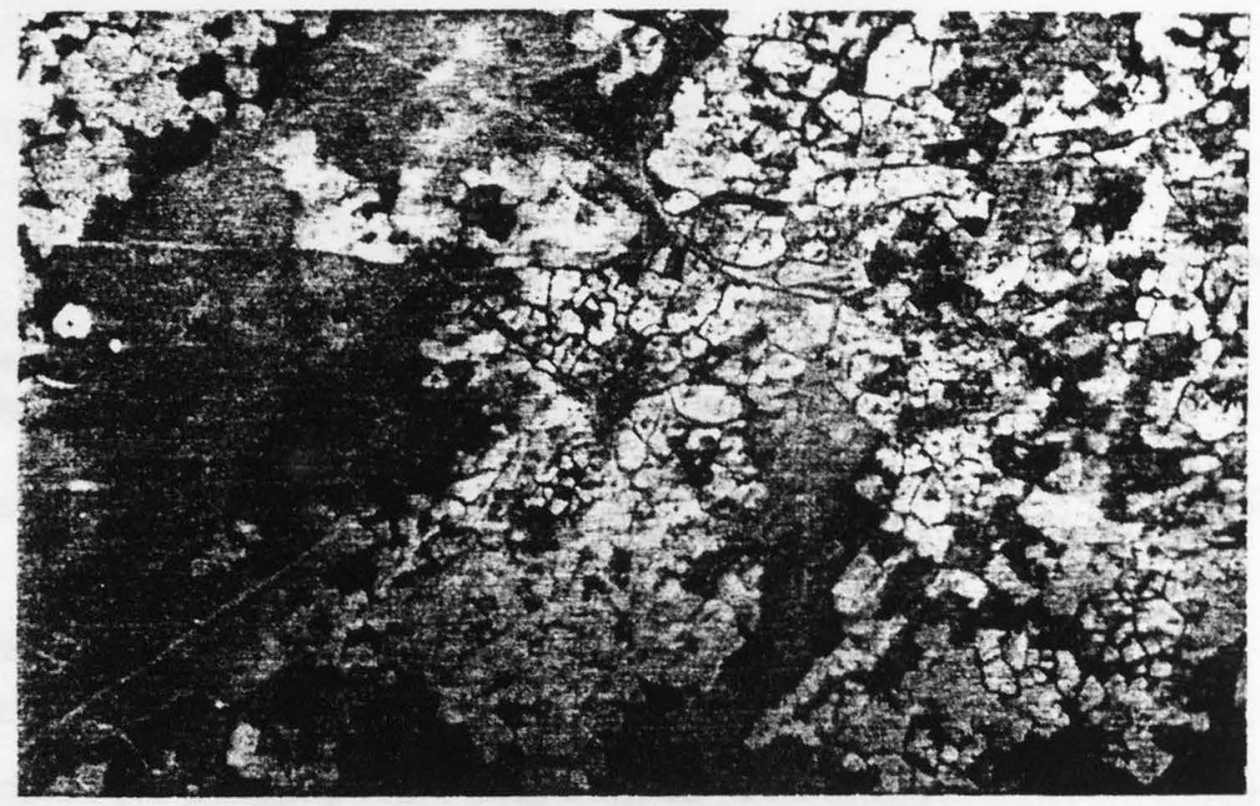

Photo 1. Air photo of the study area taken in 1954. It was used with another photo of the area taken in 1980 to create a land use and land cover map pair (see Figure 1).

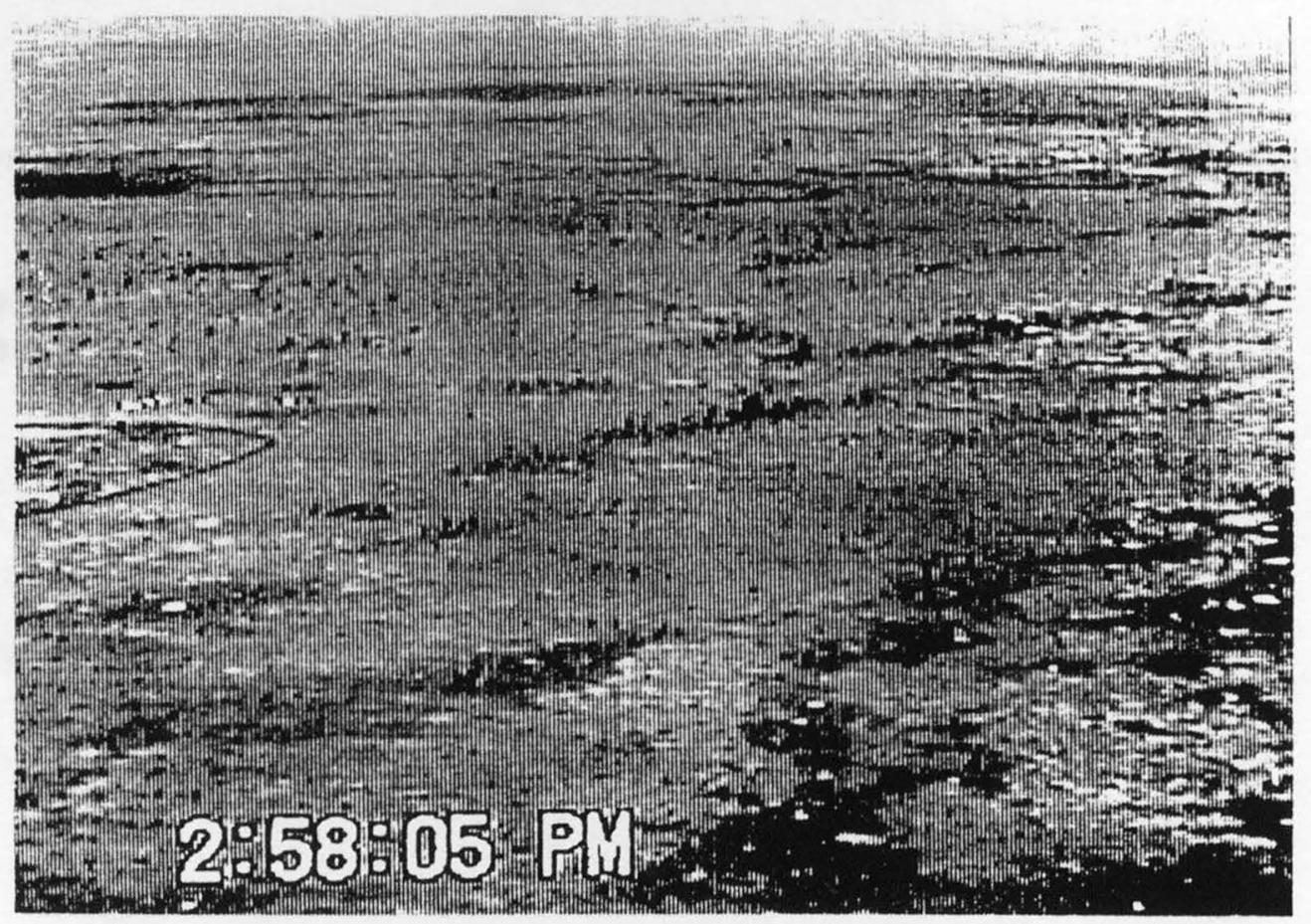

Photo 2. Trees on the hurum gese. Note the village enclosure on the left side of the scene. The scene was captured using oblique aerial videography. 


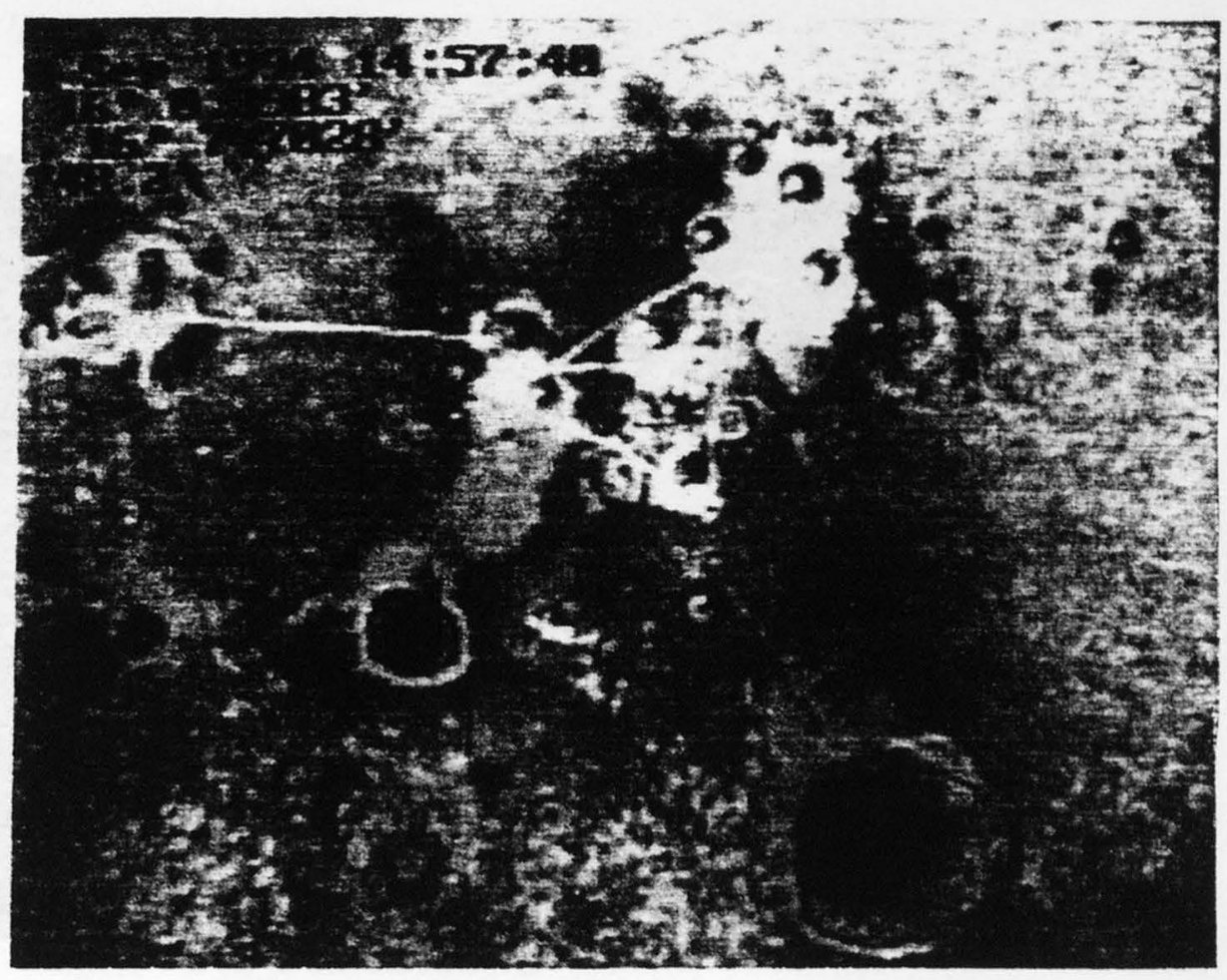

Photo 3. This scene, captured using vertical aerial videography, shows the layout of a typical wuro, a small group of straw houses.

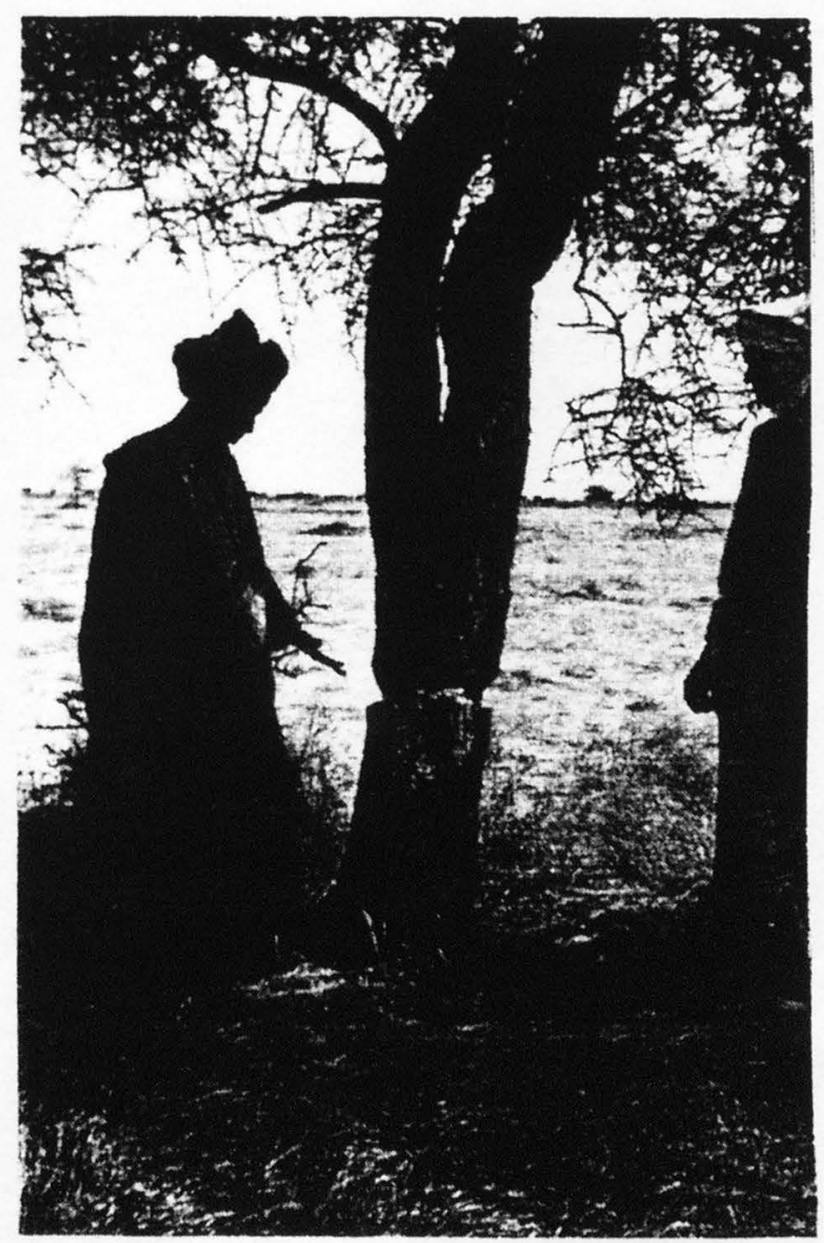

Photo 4. A local resident showing how a tree had been "banded" by stripping a section of bark around the trunk. This practice will eventually kill the tree. 


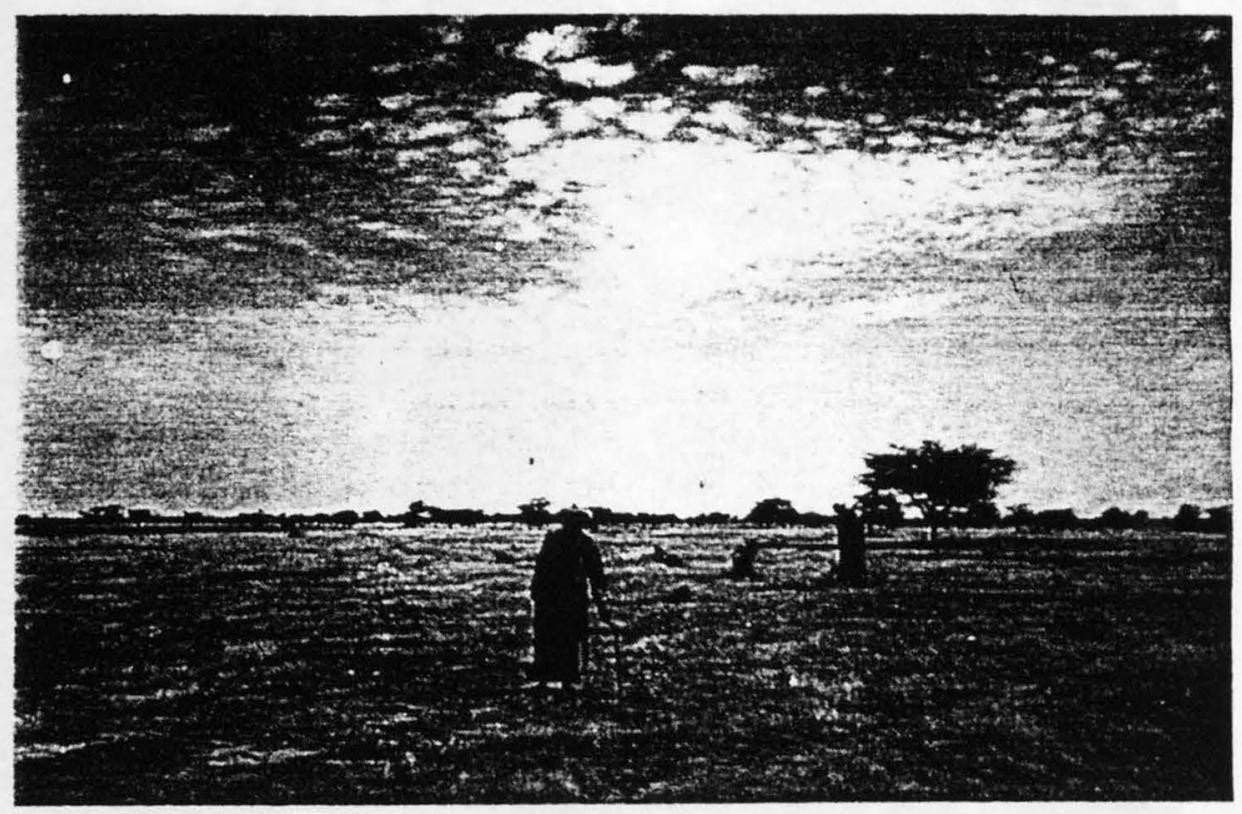

Photo 5. Local resident pointing out three stakes which indicate a neighboring farmer's intention to put the land into cultivation in the coming rainy season. 
